\title{
Article \\ Genome-Wide Analyses of the Temperature-Responsive Genetic Loci of the Pectinolytic Plant Pathogenic Pectobacterium atrosepticum
}

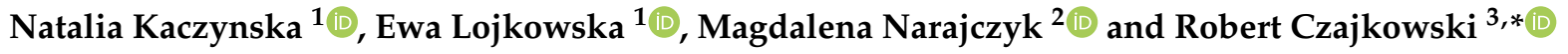 \\ 1 Laboratory of Plant Protection and Biotechnology, Intercollegiate Faculty of Biotechnology, \\ University of Gdansk and Medical University of Gdansk, Antoniego, Abrahama 58, 80-307 Gdansk, Poland; \\ natalia.kaczynska@ug.edu.pl (N.K.); ewa.lojkowska@ug.edu.pl (E.L.) \\ 2 Laboratory of Electron Microscopy, Faculty of Biology, University of Gdansk, Wita Stwosza 59, \\ 80-308 Gdansk, Poland; magdalena.narajczyk@ug.edu.pl \\ 3 Laboratory of Biologically Active Compounds, Intercollegiate Faculty of Biotechnology, University of Gdansk \\ and Medical University of Gdansk, Antoniego, Abrahama 58, 80-307 Gdansk, Poland \\ * Correspondence: robert.czajkowski@ug.edu.pl; Tel.: +48-58-5236333
}

Citation: Kaczynska, N.; Lojkowska, E.; Narajczyk, M.; Czajkowski, R. Genome-Wide Analyses of the Temperature-Responsive Genetic Loci of the Pectinolytic Plant Pathogenic Pectobacterium atrosepticum. Int. J. Mol. Sci. 2021, 22, 4839. https://doi.org/ 10.3390/ijms22094839

Academic Editor: Anne M. Alvarez

Received: 31 March 2021

Accepted: 27 April 2021

Published: 3 May 2021

Publisher's Note: MDPI stays neutral with regard to jurisdictional claims in published maps and institutional affiliations.

Copyright: (c) 2021 by the authors. Licensee MDPI, Basel, Switzerland. This article is an open access article distributed under the terms and conditions of the Creative Commons Attribution (CC BY) license (https:// creativecommons.org/licenses/by/ $4.0 /)$.

\begin{abstract}
Temperature is one of the critical factors affecting gene expression in bacteria. Despite the general interest in the link between bacterial phenotypes and environmental temperature, little is known about temperature-dependent gene expression in plant pathogenic Pectobacterium atrosepticum, a causative agent of potato blackleg and tuber soft rot worldwide. In this study, twenty-nine P. atrosepticum SCRI1043 thermoregulated genes were identified using Tn5-based transposon mutagenesis coupled with an inducible promotorless gus $A$ gene as a reporter. From the pool of 29 genes, 14 were up-regulated at $18{ }^{\circ} \mathrm{C}$, whereas 15 other genes were up-regulated at $28^{\circ} \mathrm{C}$. Among the thermoregulated loci, genes involved in primary bacterial metabolism, membrane-related proteins, fitness-corresponding factors, and several hypothetical proteins were found. The Tn 5 mutants were tested for their pathogenicity in planta and for features that are likely to remain important for the pathogen to succeed in the (plant) environment. Five Tn 5 mutants expressed visible phenotypes differentiating these mutants from the phenotype of the SCRI1043 wild-type strain. The gene disruptions in the Tn 5 transposon mutants caused alterations in bacterial generation time, ability to form a biofilm, production of lipopolysaccharides, and virulence on potato tuber slices. The consequences of environmental temperature on the ability of P. atrosepticum to cause disease symptoms in potato are discussed.
\end{abstract}

Keywords: Erwinia atroseptica; gene expression regulation; transposon; ecology; climate change

\section{Introduction}

Potato (Solanum tuberosum L.) is one of the main food crops worldwide. It is currently grown over an area estimated at 17 million hectares, with an annual yield estimated at 370 million tons [1]. Potato is generally a crop of temperate climates, but it is also grown in subtropical and tropical areas, demonstrating its adaptability to a wide range of environmental conditions.

Among the most harmful and devastating bacterial diseases affecting worldwide potato production are potato blackleg of field-grown plants and tuber soft rot during storage and transit. Both diseases are caused by pectinolytic Soft Rot Pectobacteriaceae (SRP): Pectobacterium spp. and Dickeya spp. [2-4].

The genus Pectobacterium currently includes 19 species [5-13], and the genus Dickeya gathers 12 recognized species [14-17]. Pectobacterium and Dickeya species are listed in the top 10 most important bacterial plant pathogens in agriculture based on their economic impact [18]. 
In addition, SRP can colonize and infect a wide range of crops other than potato and also infects ornamental plants. These bacteria can be present in plant tissue in latent infection, not causing any disease symptoms on host crops. Pectobacterium spp. and Dickeya spp. are also isolated from weeds and wild plants, irrigation and surface waters, insects, as well as from contaminated agricultural tools and equipment [4,19-24].

The distribution of the SRP is determined by the biotic and abiotic conditions under which the bacteria can persist and infect plants in the environment. Temperature is considered as one of the most important factors affecting disease development caused by SRP $[25,26]$. Pectobacterium spp. and Dickeya spp. differ in their optimal growth temperatures. For example, it has been demonstrated that $P$. atrosepticum grows faster at lower air temperatures $\left(<25^{\circ} \mathrm{C}\right)$; the optimal growth temperature for P. parmentieri and P. brasiliense in vitro is near $30^{\circ} \mathrm{C}$, while the optimal temperature for $D$. solani is ca. $35^{\circ} \mathrm{C}[19,26,27]$.

Until the end of the last century, P. atrosepticum and D. dianthicola were considered responsible for most potato blackleg infections in Europe [2,4,23,27-29]. Around the 2000s, D. solani has become an important cause of blackleg and soft rot in Europe [3,4,30,31]. This pathogen has spread across Europe very rapidly and has been detected on potato in most European countries [4,23,30,32,33]. However, since 2012, a shift from D. solani as the dominant blackleg causing the agent to P. parmentieri and P. brasiliense has been observed [23,34-37]. P. atrosepticum still remains the dominant species causing potato blackleg and soft rot in specific temperate regions, including the United Kingdom, Norway, and Canada [38-41]. Results from the seed potato survey between 2013 and 2015 in England, Wales, and Scotland indicate that P. atrosepticum constituted over $89 \%$ of all positive samples [41]. P. atrosepticum was also one of the most frequently detected Pectobacterium species detected during surveys 2015-2017 in Northern Ireland [42].

P. atrosepticum (formerly known as Erwinia carotovora subsp. atroseptica) is considered a narrow host range pathogen restricted mainly to potato [43]. Nevertheless, the disease symptoms caused by P. atrosepticum have also been reported in pepper [44] and sunflower [45], where it caused soft rot. A relatively narrow host range may suggest that P. atrosepticum has lost genes required for pathogenesis on other plants or has acquired genes that limit its host range $[46,47]$. P. atrosepticum is principally found in cooler temperate regions worldwide, causing symptoms at average temperatures below $25^{\circ} \mathrm{C}[2,43]$. In contrast to many of the other SRPs, it does not grow at temperatures above $36{ }^{\circ} \mathrm{C}[5,48]$.

The climate change associated with increasing average temperatures over the growing season may cause a temperature-induced shift in the distribution of Dickeya spp. and Pectobacterium spp. worldwide. Various studies have demonstrated the effect of temperature on species dominance [19,27,49-51]. It has been shown that temperature modifies which pathogen predominates if more than one SRP species is present inside a rotting seed tuber [2]. Temperature also controls the expression of virulence factors in plant pathogens during infections. In contrast to human and animal pathogens, in plant pathogenic bacteria, many virulence genes are induced at lower temperatures $\left(16-24^{\circ} \mathrm{C}\right)$ and repressed at $28^{\circ} \mathrm{C}$, although their optimal growth temperatures range from 25 to $30^{\circ} \mathrm{C}$ [52-56]. For instance, in P. atrosepticum, pectate lyase activity was reported to be maximal at $15-17^{\circ} \mathrm{C}$ [57] and reduced at $30.5^{\circ} \mathrm{C}[58]$.

Research of the past decades has revealed the general interest in bacterial phenotypes associated with growth temperatures. However, only a few model systems for thermoresponsiveness in plant pathogens have been reported until now [59-61]. Understanding how SRP adapts to different temperatures and how climate change influences the epidemiology of the diseases they cause in Europe is fundamental in the agricultural and food industry.

The purpose of this study was to characterize these P. atrosepticum transcriptional units (genes/operons) encoding factors contributing to environmental fitness and in planta virulence that were expressed exclusively at one of the two chosen temperatures (18 or $28^{\circ} \mathrm{C}$ ). This strategy was employed to help explain the observed shift of SRP pathogens in Europe from P. atrosepticum (dominant potato blackleg and soft rot pathogen in the 
past) to new emerging potato pathogens, including $D$. solani. For that, we used a random mutagenesis approach for the P. atrosepticum strain SCRI1043 [62,63], using Tn5 with a promotorless gus $A$ reporter gene [64]. This approach depends on the Tn5-gus $A$ transposons that merge target operons or genes with the promotorless reporter gus $A$. Expression of the gus $A$ reporter occurs only when the expression of the gene/operon carrying the Tn5 transposon is activated. To identify temperature-regulated transcriptional units, we applied a rigorous gene selection protocol in which all genes/operons that were expressed at both temperatures $\left(18\right.$ and $28^{\circ} \mathrm{C}$ ) were removed from our further analyses in a preliminary step. This allowed us to disclose bacterial genes/operons expressed exclusively in one or the other temperature. Selected thermoregulated loci were sequenced and further characterized to get insights into the role of temperature in the ecology of P. atrosepticum.

\section{Results}

\subsection{Transposon Mutagenesis and Visual Estimation of $\beta$-glucuronidase Activity}

A total of 5775 mutants of $P$. atrosepticum wild-type strain SCRI1043 were obtained after mutagenesis and screened for thermoregulated phenotypes. The estimated frequency of mini-Tn 5 transposon transfer from the donor E. coli S17-1 $\lambda$-pir to recipient P. atrosepticum SCRI1043 was ca. $10^{-5}$ cells/recipient. The $\beta$-glucuronidase activity of all generated mutants was compared visually in duplicates at low $\left(18^{\circ} \mathrm{C}\right)$ and high $\left(28^{\circ} \mathrm{C}\right)$ temperatures on a solid M9 minimal medium supplemented with X-Gluc. Colonies of the individual P. atrosepticum mutants exhibited varied levels of GUS activity. The majority of tested P. atrosepticum SRI1043 mutants (around 98\%) showed no difference in their GUS activity at low and high temperatures. A total of 109 mutants out of 5775 appeared to be thermoregulated with higher GUS activity at either 18 or $28^{\circ} \mathrm{C}$ (blue and dark blue colonies) and were thus chosen for quantitative GUS assays.

\subsection{Quantitative Spectrophotometric and Fluorometric GUS Assay}

The 109 P. atrosepticum transposon mutants, showing thermoresponsive GUS phenotypes, were further tested in two subsequent quantitative assays: spectrophotometric and fluorometric GUS assays. GUS activity was considered temperature-dependent when the ratio of absolute GUS values (expressed as $\mathrm{U} / \mu \mathrm{g}$ protein) obtained by fluorometric assay from 18 and $28^{\circ} \mathrm{C}$ cultures was more significant than 1.5 or less than -1.5 . Out of the 109 mutants tested, 40 mutants demonstrated significant temperature-dependent GUS activity, indicating that the miniTn 5 transposon has been inserted downstream from the thermoregulated promoter. From those, 20 transposon mutants showed an increased GUS activity at $18{ }^{\circ} \mathrm{C}$, and 20 mutants exhibited a high GUS activity at $28^{\circ} \mathrm{C}$. Relative GUS activity of the mutants at $18{ }^{\circ} \mathrm{C}$ ranged from 0.6 to $250 \mathrm{U} / \mu$ g protein and at $28^{\circ} \mathrm{C}$ ranged from 0.5 to $170 \mathrm{U} / \mu \mathrm{g}$ protein. The level of temperature induction expressed as the GUS activities ratio at $18^{\circ} \mathrm{C}$ versus $28^{\circ} \mathrm{C}$ or vice versa varied between 1.5 - and 5-fold.

\subsection{Phenotypic Characterization of P. atrosepticum Transposon Mutants}

To investigate the physiological effect of the mutations in the temperature-regulated genes, 40 selected transposon mutants of P. atrosepticum SCRI1043 showing at least 1.5-fold change in the relative GUS activity at $18{ }^{\circ} \mathrm{C}$ or $28^{\circ} \mathrm{C}$ were compared with the wild-type P. atrosepticum SCRI1043 for differences in their phenotypic characteristics such as cell morphology, exoenzyme production, motility, biofilm formation, in vitro growth rate, and ability to rot potato tuber tissue.

In comparison with the wild-type P. atrosepticum SCRI1043, none of the 40 analyzed transposon mutants showed differences in cell morphology in TEM analysis (data not shown). Likewise, the transposon mutants did not show any significant difference from the parental strain in swimming motility at $28^{\circ} \mathrm{C}$. However, in mutant PbaTn5-B76, the swimming motility was reduced compared to the wild-type P. atrosepticum SCRI1043 grown at $22{ }^{\circ} \mathrm{C}$. 
The level of exoenzyme production of P. atrosepticum transposon mutants and SCRI1043 was assessed by picking bacterial colonies onto enzyme assay plates for pectate lyases, cellulases, and proteases. All indicator plates showed a statistically significant reduction in the amount of enzyme produced only by one mutant, PbaTn5-B76, compared with SCRI1043, as determined by halo size (Table S1).

The growth curves of the 40 transposon mutants grown in M9 minimal medium supplemented with $0.4 \%$ glycerol as the sole carbon source were determined. The growth of the mutants PbaTn5-B76, PbaTn5-B58 and PbaTn5-43, was significantly slower than that of the wild-type SCRI1043 strain (Figure 1). The doubling times of PbaTn5-B76, PbaTn5B58, PbaTn5-43 (1.9-2.0 h) were longer than the doubling time of SCRI1043 (1.4 h). The growth of the other 37 mutants was not significantly different from that of their parental SCRI1043 wild-type strain.

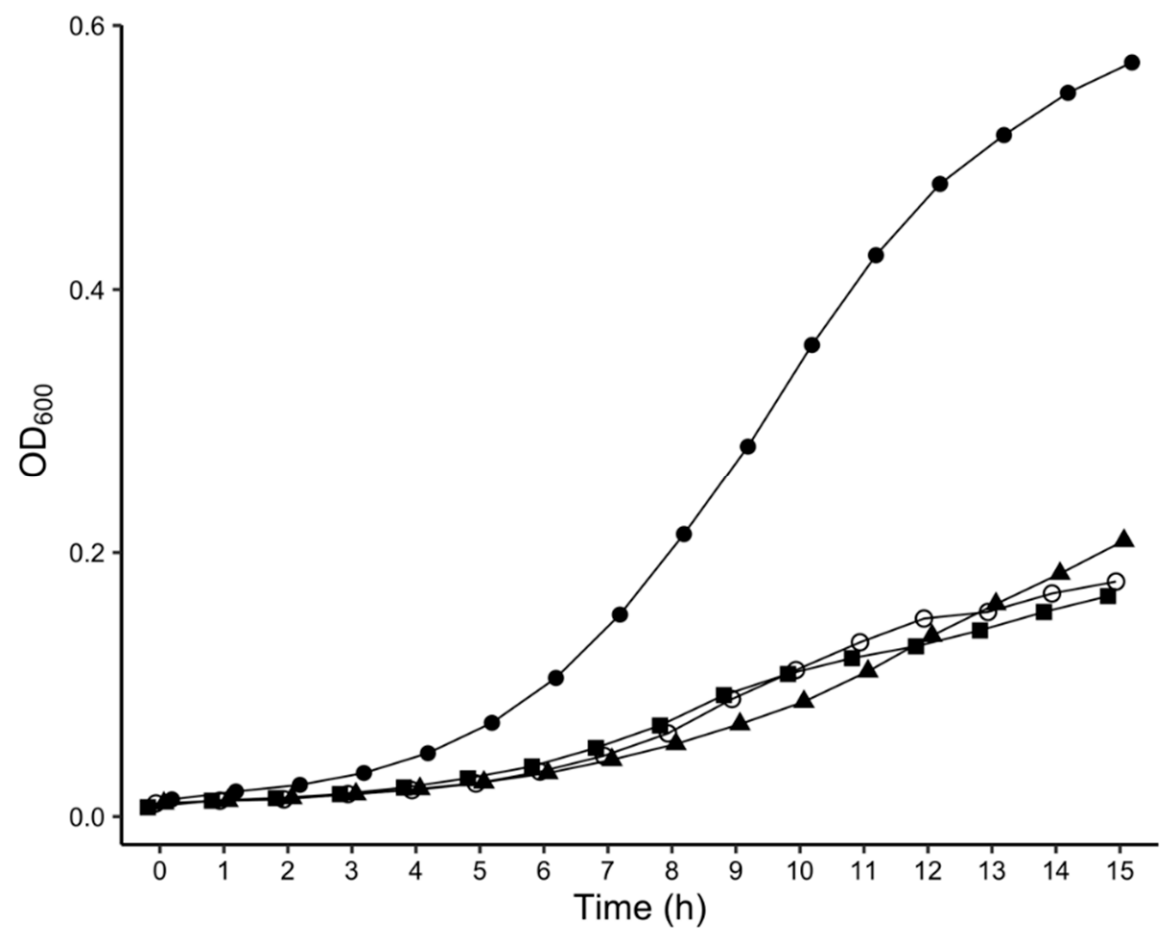

Figure 1. Growth curves of P. atrosepticum wild-type strain SCRI1043 (closed circle) and mutant strains PbaTn5-43 (closed square), PbaTn5-B58 (open circle), and PbaTn5-B76 (closed triangle) grown in M9 minimal media supplemented with $0.4 \%$ glycerol. The figure depicted only mutants where bacterial growth was significantly different from that of the wild-type P. atrosepticum SCRI1043. Bacterial growth was determined by measuring $\mathrm{OD}_{600}$ against a medium blank. The values are expressed as the mean ( $n=6$ from two independent experiments).

The biofilm formation ability of transposon mutants was investigated using a crystal violet staining assay in polypropylene Eppendorf tubes. The results indicated that the P. atrosepticum SCRI1043 wild-type strain and all the mutant strains formed a biofilm on the inner surface of the polypropylene Eppendorf tubes. However, the level of biofilm formation capacity was relatively low. Three transposon mutants, PbaTn5-43, Pba-B58, and PbaTn5-B76, showed significantly enhanced biofilm formation compared to that of the wild-type SCRI1043 $(p<0.05)$ when the M9 minimal medium was supplemented with $0.4 \%$ glycerol (Figure 2). The biofilm formation ability of the mutant PbaTn5-B31, was significantly reduced compared to that of the wild-type strain SCRI1043. 


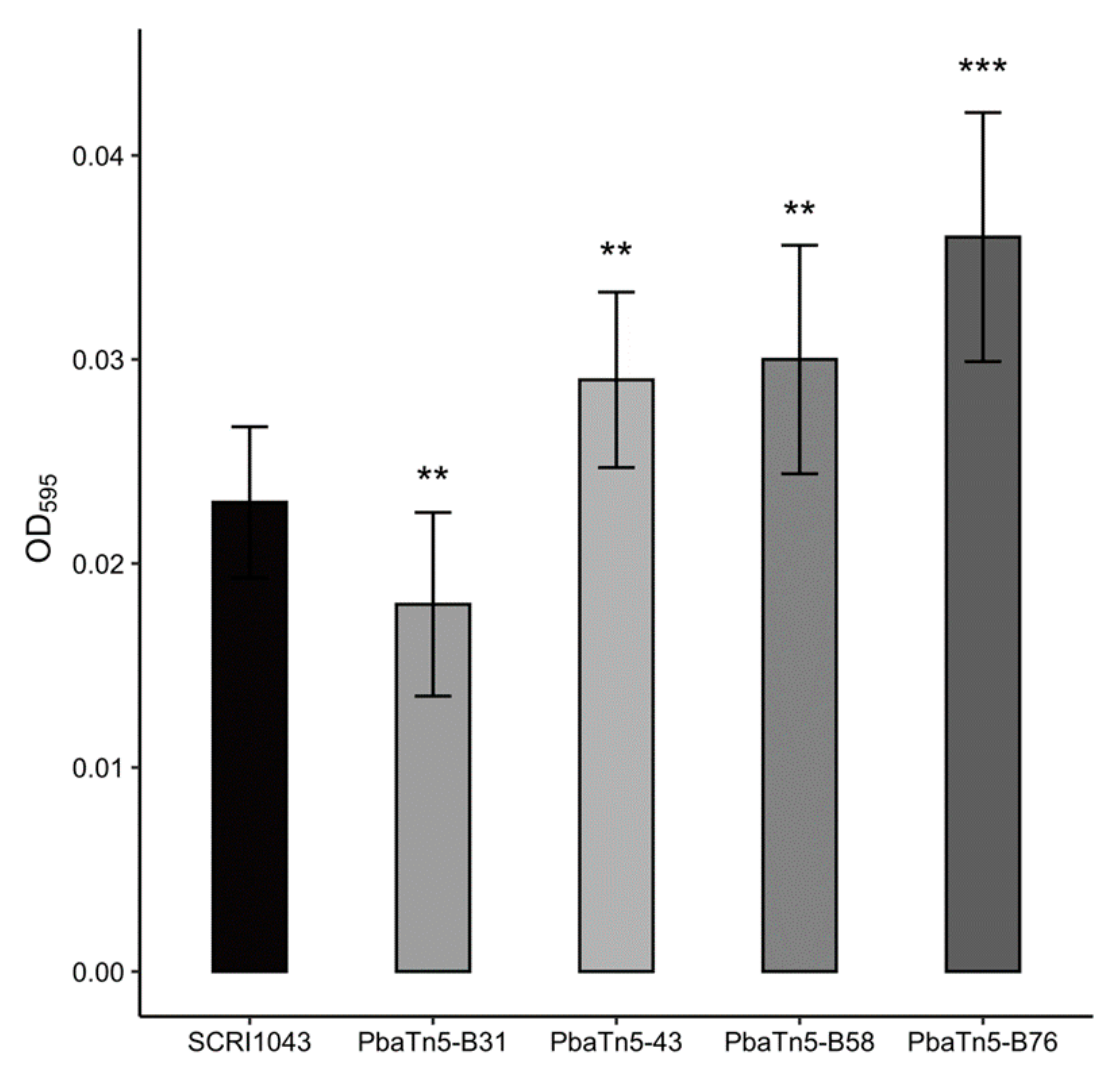

Figure 2. The in vitro biofilm formation ability of P. atrosepticum SCRI1043 wild-type strain and mutant strains differed in M9 minimal media supplemented with $0.4 \%$ glycerol. The figure depicted only mutants where the biofilm formation level was significantly different from the wild-type P. atrosepticum SCRI1043. All strains were examined in two independent experiments with duplicate samples, and the error bars indicate standard deviations. Statistically significant differences in biofilm formation between wild-type $P$. atrosepticum SCRI1043 and mutant strains are indicated ${ }^{* * *} p<0.001$; ** $p<0.01$ ) and were determined by the Student's $t$-test.

\subsection{Virulence of P. atrosepticum Tn5 Mutants}

To investigate the possible effect of transposon mutations on the virulence of $P$. atrosepticum, the ability of SCRI1043 and selected Tn5 transposon mutants to rot potato tuber tissue was investigated. The majority ( $95 \%$ ) of the transposon mutants did not show any difference in tissue maceration capacity compared with the wild-type strain SCRI1043. The transposon mutant PbaTn5-B76 exhibited a significant decrease in the ability to macerate potato tuber tissue $(85 \%$, at $p<0.05)$ in comparison with the maceration ability of the wild-type strain SCRI1043 (Figure 3). In contrast, mutant PbaTn5-A43, showed a 50\% elevated ability to macerate potato tubers than the one observed in the case of the wild-type strain SCRI1043.

The LPS profile of PbaTn5-B76 was investigated. LPS samples were analyzed by SDS gel electrophoresis. The PbaTn5-B76 mutant exhibited a truncated LPS as compared with the parental wild-type strain LPS. It is noteworthy that the total amount of LPS present in the PbaTn5-B76 appeared very much reduced (Figure S1A). Furthermore, the PbaTn5B76 mutant showed weaker lactose fermentation when was plated on MacConkey agar compared to the wild-type strain SCRI1043 (Figure S1B). 


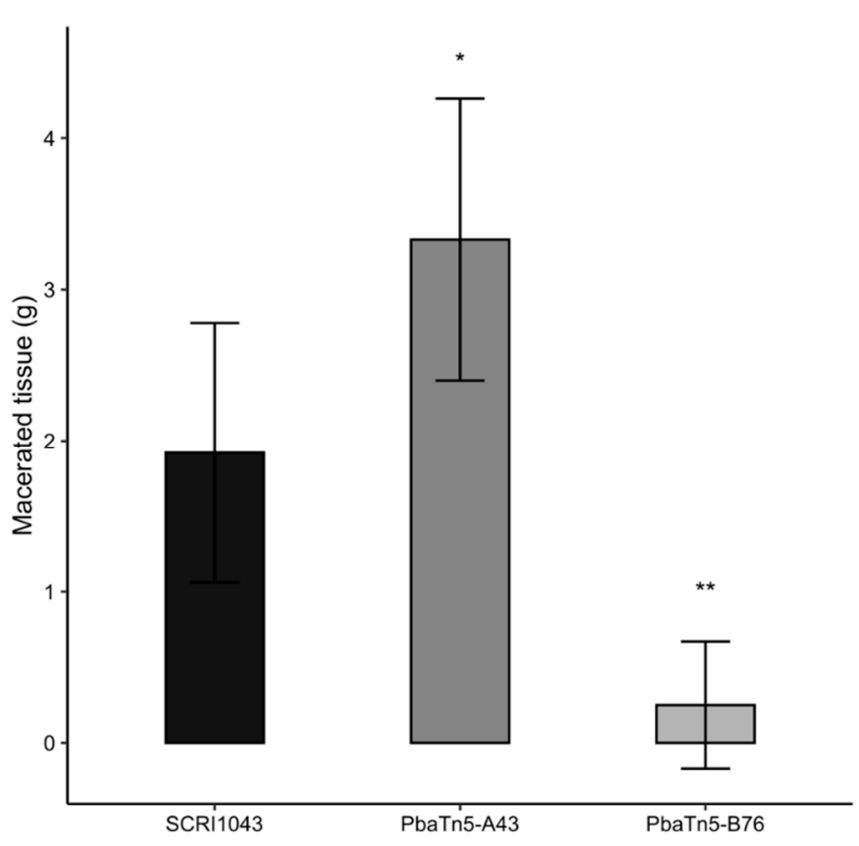

Figure 3. Maceration ability of the wild-type strain P. atrosepticum SCRI1043 and transposon mutant strains on potato tuber slices. The figure depicted only mutants where the level of potato tissue macerating ability was significantly different from that in wild-type P. atrosepticum SCRI1043. Bacteria ( $10^{6}$ per inoculation) of the wild-type strain and mutant strains were inoculated into wells on potato tuber slices. The maceration capacity of mutants (in grams of macerated tissue) was measured after $72 \mathrm{~h}$ of incubation at $28^{\circ} \mathrm{C}$. The error bars represent the SD of the $n=6$ potato tuber slices. Asterisks indicate statistically significant differences in the degree of maceration of the mutants compared with the wild-type strain P. atrosepticum SCRI1043 (** $\left.p<0.01{ }^{*} p<0.05\right)$, determined by the Student's $t$-test.

\subsection{Characterization of Transposon Insertion Sites}

The transposon flanking regions for 29 transposon mutants of P. atrosepticum SCRI1043, which showed greater fold change of GUS activity or significant phenotypic difference from the parental strain, were sequenced and comparatively analyzed using BLAST against the sequenced P. atrosepticum genome strain SCRI1043 (accession no. BX950851) [63]. Analysis of the nucleotide sequences flanking the transposon insertion revealed that each mutant resulted from a unique insertion event. The insertions were in different loci throughout the genome of P. atrosepticum SCRI1043 (Figure 4A). Among the thermoregulated loci were those involved in bacterial metabolism (aminohydrolase, siderophore biosynthesis proteins, metallo- $\beta$-lactamase, transcriptional regulators), signal transduction mechanisms (sigma-E factor regulatory proteins), chaperons (chaperone protein $\mathrm{ClpB}$ ), and also those involved in cell wall biogenesis (UDP-phosphate galactose phosphotransferase, UTP-glucose-1phosphate uridylyltransferase) (Table 1).

The proteins encoded by the 29 thermoregulated loci identified in this study were grouped into functional categories using the clusters of orthologous groups of proteins (COGs) from EggNOG database [65], as shown in Table 1. Of these, in mutants with increased GUS activity at $18{ }^{\circ} \mathrm{C}$, five proteins were classified in Cellular processes and signaling related categories $(\mathrm{O}, \mathrm{M}, \mathrm{T})$; four proteins were represented in Metabolism related categories $(G, P)$; Information storage and processing related categories included one protein (J); Poorly characterized COG group $S$ contained four proteins (Figure $4 \mathrm{~B}$ ). In mutants with increased GUS activity at $28^{\circ} \mathrm{C}$ metabolism categories (C, G, Q) included five proteins; three proteins were classified in Information storage and processing related categories ( $\mathrm{J}$, L); two proteins were represented in Cellular processes and signaling categories $(\mathrm{O}, \mathrm{M})$; Poorly characterized COG group S contained five proteins (Figure $4 \mathrm{~B}$ ). 
Table 1. Description of thermoresponsive loci of P. atrosepticum SCRI1043 transposon mutants.

\begin{tabular}{|c|c|c|c|c|c|c|}
\hline Number & Mutant & $\begin{array}{c}\% \text { Identity }{ }^{\text {a }} \text {; Protein, Accession Number; } \\
\text { Gene }^{\mathrm{b}} ; \mathrm{TU}^{\mathrm{c}}\end{array}$ & Predicted Function & $\begin{array}{l}\text { Fold Induction }{ }^{\mathrm{d}} \text { of } \\
\text { GUS Activity }\end{array}$ & Function Group (COGs) ${ }^{e}$ & Differential Phenotype \\
\hline \multicolumn{7}{|c|}{ Mutants with increased GUS activity at $18^{\circ} \mathrm{C}$} \\
\hline 1 & PbaTn5-38 & 99; CAG74583.1; ECA_RS08290; PTU & Transcriptional regulator & 1.6 & COG2336T & $\mathrm{WT}^{\mathrm{f}}$ \\
\hline 2 & PbaTn5-43 & $\begin{array}{c}\text { 100; WbaP; CAG74330.1; ECA_RS07075 (rfbP); } \\
\text { MTU }\end{array}$ & $\begin{array}{l}\text { UDP-phosphate galactose } \\
\text { phosphotransferase }\end{array}$ & 2.0 & COG2148M & $\begin{array}{l}\text { enhanced biofilm formation, } \\
\text { reduced growth }\end{array}$ \\
\hline 3 & PbaTn5-A6 & 95; H-NS; CAG75793.1; ECA_RS14220; MTU & DNA-binding protein H-NS & 1.5 & $\begin{array}{c}\text { COG2916S } \\
\text { ENOG501RF2B }\end{array}$ & WT \\
\hline 5 & PbaTn5-A27 & 100;CAG74551.1;ECA_RS08155; MPU & Hypothetical protein ECA1647 & 1.9 & ENOG502FKDA & WT \\
\hline 6 & PbaTn5-A29 & 100;CAG74078.1; ECA_RS05790; PTU & Putative 50S ribosomal protein L31 & 1.6 & COG0254J & WT \\
\hline 7 & PbaTn5-B9 & 90;CAG73972.1; ECA_RS05265; PTU & Putative integrase & 2.1 & COG4688S & WT \\
\hline 8 & PbaTn5-B16 & 100;CAG75691.1;ECA_RS13700; MTU & Putative glutatione S-transferase & 1.5 & COG0625O & WT \\
\hline 9 & PbaTn5-B31 & 100;CAG72938.1; ECA_RS00065; PTU & Ribokinase & 2.6 & COG0524G & reduced biofilm formation \\
\hline 10 & PbaTn5-B36 & 100;CAG77284.1; ECA_RS21710; PTU & $\begin{array}{c}\text { IIABC component of } \\
\text { phosphoenolpyruvate-dependent sugar } \\
\text { phosphotransferase (PTS) system }\end{array}$ & 1.5 & COG1263G & WT \\
\hline 12 & PbaTn5-B63 & 100;CAG77013.1; ECA_RS20345; MTU & $\begin{array}{l}\text { Putative IucA/IucC family siderophore } \\
\text { biosynthesis protein }\end{array}$ & 2.0 & COG4264P & WT \\
\hline 13 & PbaTn5-B76 & $\begin{array}{c}\text { 96; GalU; CAG75232.1; ECA_RS11440 (gall); } \\
\text { MTU }\end{array}$ & $\begin{array}{l}\text { UTP-glucose-1-phosphate } \\
\text { uridylyltransferase }\end{array}$ & 1.6 & COG1210M & $\begin{array}{l}\text { reduced swimming motility, } \\
\text { reduced exoenzyme } \\
\text { production, reduced } \\
\text { growth, enhance biofilm } \\
\text { formation, reduced ability } \\
\text { to macerate potato tissue, } \\
\text { altered LPS synthesis, } \\
\text { altered lactose fermentation }\end{array}$ \\
\hline 14 & PbaTn5-B78 & $\begin{array}{l}\text { 100; MucB, RseB; CAG76180.1; } \\
\text { ECA_RS16150; MTU }\end{array}$ & Sigma-E factor regulatory protein & 1.8 & COG3026T & WT \\
\hline
\end{tabular}


Table 1. Cont.

\begin{tabular}{|c|c|c|c|c|c|c|}
\hline Number & Mutant & $\begin{array}{c}\% \text { Identity }{ }^{a} ; \text { Protein, Accession Number; } \\
\text { Gene }{ }^{b} ; \text { TU }^{c}\end{array}$ & Predicted Function & $\begin{array}{l}\text { Fold Induction }{ }^{\mathrm{d}} \text { of } \\
\text { GUS Activity }\end{array}$ & Function Group (COGs) ${ }^{e}$ & Differential Phenotype \\
\hline \multicolumn{7}{|c|}{ Mutants with increased GUS activity at $28^{\circ} \mathrm{C}$} \\
\hline 15 & PbaTn5-1 & 98;CAG73522.1;ECA_RS03020; PTU & Cfa- $\beta$-ketoacyl synthase & 2.2 & COG0304IQ & WT \\
\hline 16 & PbaTn5-4 & 100; ClpB; CAG76243.1; ECA_RS16515; MTU & Chaperone protein $\mathrm{ClpB}$ & 2.8 & COG0542O & WT \\
\hline 17 & PbaTn5-8 & 100; CAG76476.1; ECA_RS17680; MTU & D-galactarate dehydratase & 2.9 & COG2721G & WT \\
\hline 18 & PbaTn5-11 & 85; CAG74973.1;ECA_RS10210; PTU & Putative cytochrome P450 & 3.8 & COG2124Q & WT \\
\hline 19 & PbaTn5-16 & 100;CAG76859.1; ECA_RS19560; MTU & Putative exported protein & 2.0 & ENOG502C5YQ & WT \\
\hline 20 & PbaTn5-26 & 91;CAG75749.1; ECA_RS13980; MTU & Metallo- $\beta$-lactamase & 2.8 & COG0491GM & WT \\
\hline 21 & PbaTn5-A2 & 93; CAG73973.1; ECA_RS05270; PTU & Conserved hypothetical protein & 5.0 & ENOG502E3II & WT \\
\hline 22 & PbaTn5-A33 & 89;CAG75864.1; ECA_RS14560; MTU & Amidohydrolase; putative peptidase & 4.7 & COG1473S & WT \\
\hline 23 & PbaTn5-A43 & 100; CAG76360.1;ECA_RS17050; PTU & Putative exported protein & 2.3 & ENOG502ASC5 & $\begin{array}{l}\text { enhanced ability to } \\
\text { macerate potato tissue }\end{array}$ \\
\hline 24 & PbaTn5-B25 & 77; HybO;CAG74135.1; ECA_RS06065; PTU & Hydrogenase-2 small subunit & 2.7 & COG1740C & WT \\
\hline 25 & PbaTn5-B30 & 100; CAG73872.1; ECA_RS04750; MTU & AAA family ATPase & 2.2 & COG0419L & WT \\
\hline 27 & PbaTn5-B53 & 99; CAG76514.1; ECA_RS17865; PTU & RNA ligase RtcB family protein & 1.6 & COG1690J & WT \\
\hline 28 & PbaTn5-B58 & 98; Wza;CAG74327.1;ECA_RS07060; PTU & Putative polysaccharide export protein & 1.7 & COG1596M & $\begin{array}{l}\text { enhanced biofilm formation, } \\
\text { reduced growth }\end{array}$ \\
\hline 29 & PbaTn5-B80 & 100;CAG73490.1; ECA_RSO2860; PTU & Putative membrane protein & 1.8 & ENOG5028UFW & WT \\
\hline
\end{tabular}

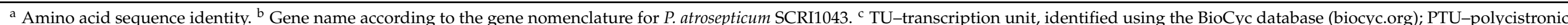

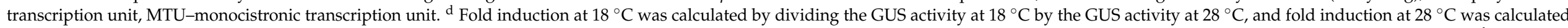

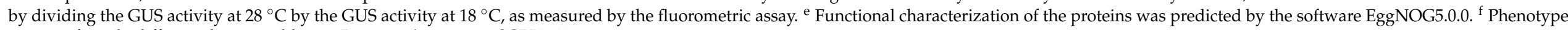
not significantly different than in wild-type P. atrosepticum strain SCRI1043. 

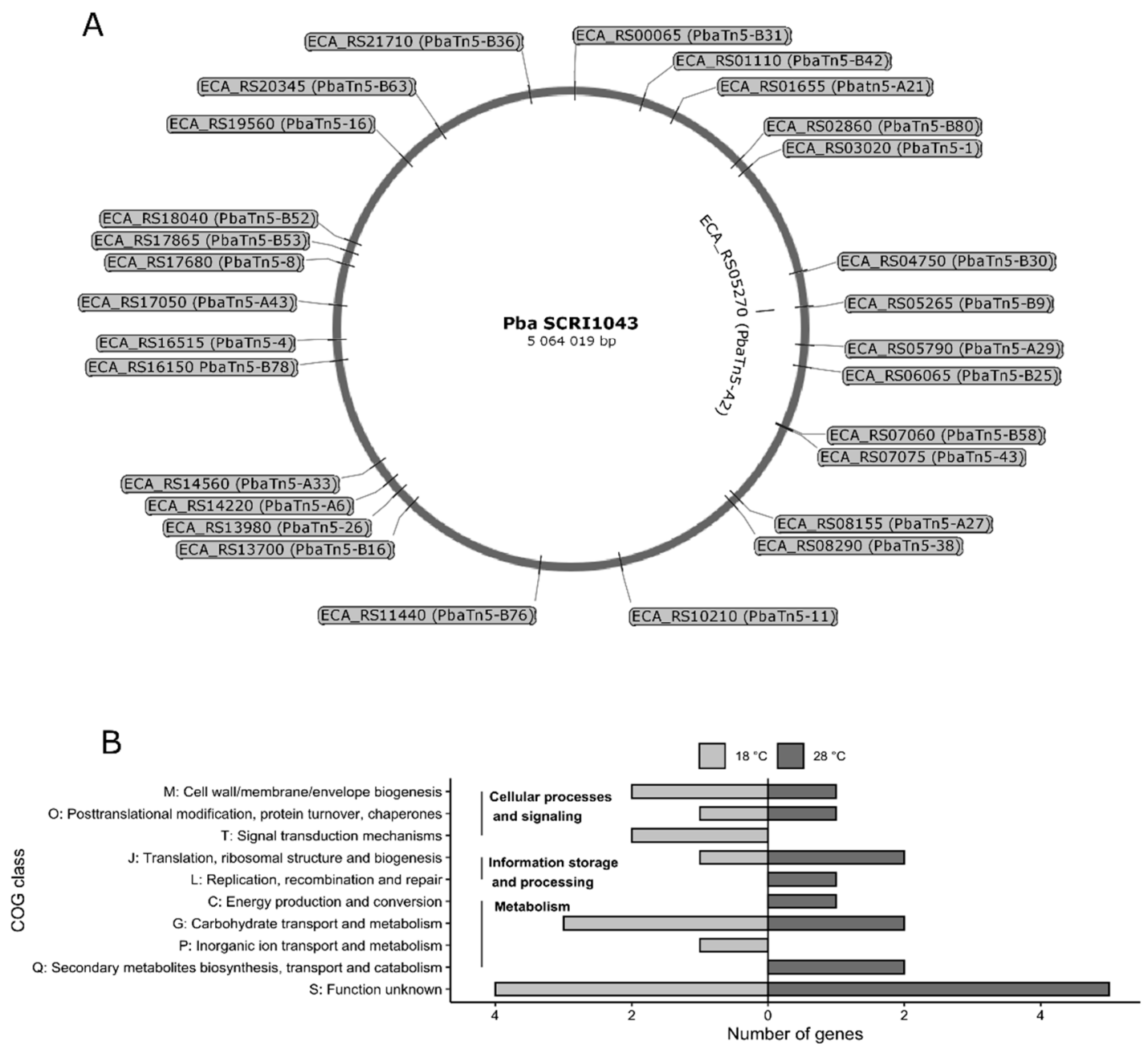

Figure 4. The distribution of the transposon insertions in the genome of P. atrosepticum strain SCRI1043. The diagram was drawn using P. atrosepticum SCRI1043 genome sequence information (GenBank: BX950851). Violet vertical lines represent the location of the transposon. The transposon mutant names (PbaTn5-x) are indicated. Gene names (ECA_RSx) according to the gene nomenclature for $P$. atrosepticum SCRI1043. The image was prepared using SnapGene ${ }^{\circledR}$ software (A). Functional categories of twenty-nine thermoregulated loci based on clusters of orthologous groups (COG). Bar plot showing the number of genes under 10 different COG categories depicted on the $y$-axis according to four broad functional groups (B).

\subsection{Time-Dependent Induction of Gene Expression Among P. atrosepticum Transposon Mutants}

To investigate the time needed for induction of GUS activity in transposon mutants of P. atrosepticum strain SCRI1043, a time-dependent experiment with samplings at different time points was performed for selected 10 P. atrosepticum transposon mutants that showed greater fold change of GUS activity (PbaTn5-48, PbaTn5-B52, PbaTn5-43, PbaTn5-A27, PbaTn5-38, PbaTn5-B76 at $18^{\circ} \mathrm{C}$ and PbaTn5-A2, PbaTn5-A33, PbaTn5-B25, PbaTn5-B42 at $28^{\circ} \mathrm{C}$ ) as described by Ullrich et al. [59]. The shift of bacterial cultures from non-inductive to inductive temperatures takes ca. $10 \mathrm{~min}$, and this time was excluded from the total assay time. Of the 10 P. atrosepticum $\mathrm{Tn} 5$ mutants tested, all expressed a steady increase in GUS activity upon transfer from one temperature to another. Figure 5 illustrates the results for the selected $P$. atrosepticum transposon mutants with a similar level of GUS activity. Generally, the transposon mutants displayed a remarkable lag phase for GUS induction $(2-7 \mathrm{~h})$, that bacteria needed to adapt to the new temperature regime before GUS 
expression was initiated. The above is in line with results obtained by Ullrich et al. [59] from experiments with P. syringae pv. glycinea.
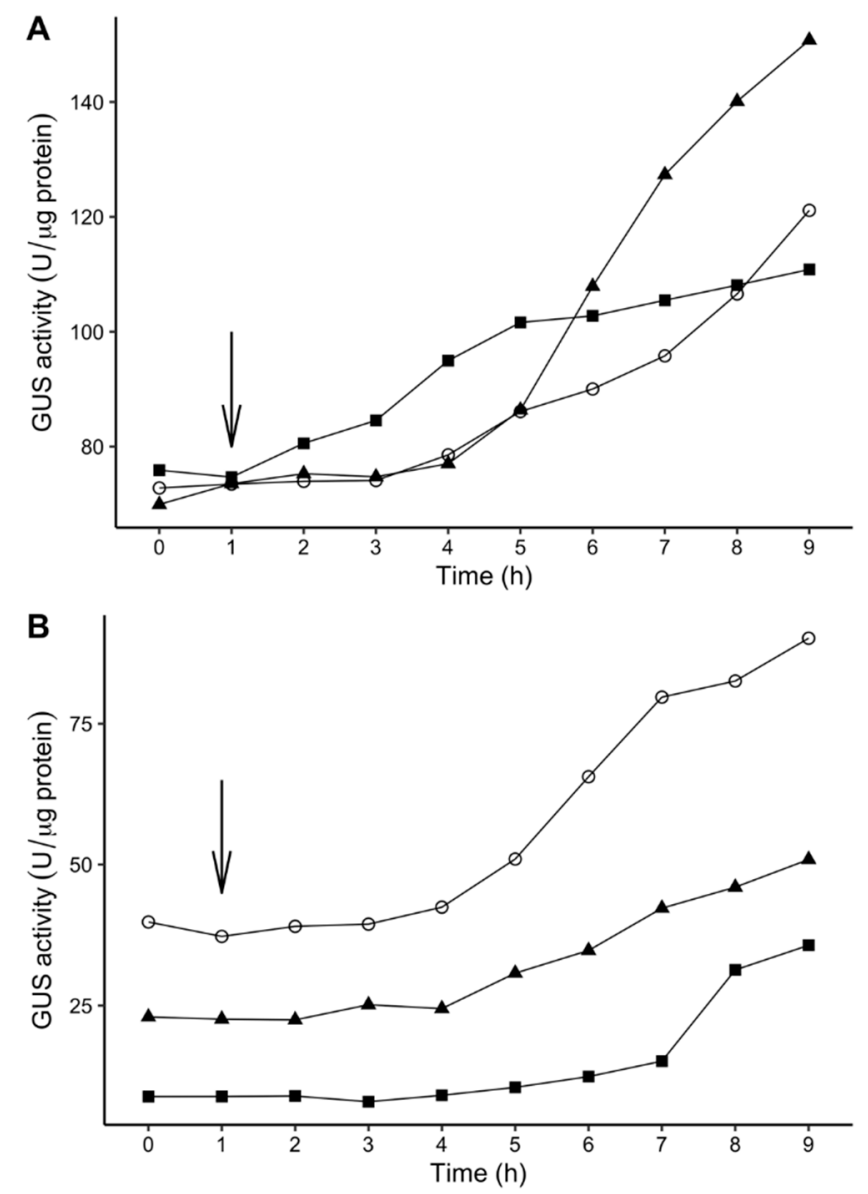

Figure 5. Effect of temperature shift on GUS activity in the transposon mutants of P. atrosepticum SCRI1043. Bacteria were grown to $\mathrm{OD}_{600}$ of $1.0(\mathrm{t}=0 \mathrm{~h})$ at the non-inductive temperature, incubated for an additional hour, and then shifted (arrow) to the $g u s A$-expression-inductive temperature. Values are the means of three replicates per strain. Effect of temperature shift from $28{ }^{\circ} \mathrm{C}$ to $18{ }^{\circ} \mathrm{C}$ on GUS activity in P. atrosepticum SCRI1043 mutants with higher levels of GUS activity at $18^{\circ} \mathrm{C}$ : PbaTn5-38 (open circle), PbaTn5-43 (closed triangle), PbaTn5-B76 (closed square) (A). Effect of temperature shift from $18{ }^{\circ} \mathrm{C}$ to $28^{\circ} \mathrm{C}$ on GUS activity in P. atrosepticum SCRI1043 mutants with higher levels of GUS activity at $28^{\circ} \mathrm{C}$ : PbaTn5-A33 (closed square), PbaTn5-B25 (open circle), PbaTn5-B42 (closed triangle) (B).

\section{Discussion}

Several studies reported that the increasing average temperatures throughout the growing season due to climate change are recognized as one of the main reasons for a shift in the distribution of Dickeya spp. and Pectobacterium spp. on potato in Europe [23,27,30,35,66,67]. Although SRPs have been studied for decades, little is still known about temperatureresponsive genes and thermoregulation of gene expression in Dickeya spp. and Pectobacterium spp. Our previous study has described the influence of temperature on gene expression in D. solani [61]. In the present study, we first attempted to establish a relation between temperature and regulation of gene expression, especially with regard to pathogenicity, in P. atrosepticum.

Out of the 5775 transposon mutants of P. atrosepticum, SCRI1043 examined, only 40 mutants (less than $1 \%$ of the total number of the obtained mutants) appear to have transposon insertions in temperature-dependent genes. The low number of the identified temperature-responsive loci in P. atrosepticum is consistent with our previous results 
obtained for D. solani [61] and the findings of similar studies on Pseudomonas syringae pv. glycinea and Erwinia amylovora [59,60].

In our previous investigation, the shift in growth temperature to a cool temperature of $18{ }^{\circ} \mathrm{C}$ altered gene expression levels, measured by GUS activity in relatively only a few mutants of $D$. solani strain IFB0099. Only nine transposon mutants out of 54 mutants of $D$. solani showed a higher GUS activity at $18{ }^{\circ} \mathrm{C}$ [61]. Contrary, in P. atrosepticum strain SCRI1043, the number of transposon mutants with higher expression of the genes, with the introduced GUS cassette, at $18{ }^{\circ} \mathrm{C}$ was 20 , the same as the number of mutants with a higher GUS activity at $28{ }^{\circ} \mathrm{C}$. It might be related to the fact that P. atrosepticum is a "cold-weather" pathogen and is thus well adapted to cool temperatures. D. solani grows in a wide range of temperatures [27], and the optimal temperature for its growth is relatively higher: $35^{\circ} \mathrm{C}$ [26]. According to these data, it is reasonable that in the cells of $D$. solani, the expression of virulence factors is induced at higher temperatures than in P. atrosepticum. This finding is consistent with the previous studies that have examined the effect of temperature on plant cell wall degrading enzyme (PCWDE) in plant pathogenic bacteria. Smadja et al. [57] demonstrated that the pectate lyase activity of P. atrosepticum was maximal at $12{ }^{\circ} \mathrm{C}$, and protease activity was induced at $17-24^{\circ} \mathrm{C}$. In the case of $D$. solani, Golanowska et al. [27] showed that this bacterium has the highest pectinolytic, cellulolytic and proteolytic activities at $28^{\circ} \mathrm{C}$ rather than at lower temperatures. Also, in closely related D. dadantii strain 3937 , the expression of pel genes encoding pectate lyases was maximal at $25{ }^{\circ} \mathrm{C}[52]$.

The possible functions for 29 temperature-regulated P. atrosepticum loci from this study were identified based on the comparison of their sequences with the sequences available in the GenBank database. The transposon was evenly inserted in different genes of the P. atrosepticum SCRI1043 genome, suggesting genome-wide insertion. Mutations targeted genes coding for proteins involved in fundamental bacterial metabolism, regulatory proteins, membrane proteins, and hypothetical proteins. However, the roles of most of them in adaptation to temperature fluctuations and infection of host plants are unclear.

The temperature-induced loci of $P$. atrosepticum identified in this study were compared to temperature-responsive loci of other plant pathogenic bacterial species, including D. solani, P. syringae pv. glycinea, and E. amylovora were identified using similar techniques [59-61] and E. coli [68]. Interestingly, several similar genetic loci were induced at the same temperature despite the different life strategies of these bacteria and their adaptation to other hosts.

In $P$. atrosepticum, the genes associated with transcription, carbohydrate transport and metabolism, cell wall and membrane biogenesis, as well as signal transduction were up-regulated at low temperatures. In P. atrosepticum, but not in D. solani, temperaturedependent gusA expression was observed in the mutants with a transposon insertion in genes involved in biosynthesis, transport, and catabolism of secondary metabolites. Transposon mutant, $\mathrm{PbaTn} 5-\mathrm{A} 6$, harbored a Tn5 insertion in a gene encoding DNA-binding protein $\mathrm{H}-\mathrm{NS}$ and showed a higher GUS activity at $18^{\circ} \mathrm{C}$. It has previously been demonstrated that H-NS plays an essential role in the adaptation of E. coli to low temperatures $[69,70]$. Nasser et al. [71] indicated that H-NS plays a crucial role in the regulation of the pathogenicity of $D$. dadantii. They demonstrated that a $h n s$ mutant of $D$. dadantii displayed reduced growth rate, motility, and virulence on plants but increased exopolysaccharides (EPS) synthesis [71]. In this study, the maceration ability of the mutant PbaTn5-A6 on potato tubers was slightly decreased, and the biofilm formation ability was increased compared to the wild-type strain. No difference in growth rates was observed between the mutant PbaTn5-A6 and the wild-type strain P. atrosepticum SCRI1043.

The transposon mutant PbaTn5-4 with a transposon insertion in the gene encoding $\mathrm{ClpB}$ protein showed an increased GUS expression at $28^{\circ} \mathrm{C}$. Previously it has been indicated that $\operatorname{clpB}$ gene expression is induced in response to heat stress and is required for growth at high temperatures $[72,73]$. Therefore, this finding of the current study confirms that 
P. atrosepticum grows better at lower temperatures $\left(<25^{\circ} \mathrm{C}\right)$, and a temperature around $28^{\circ} \mathrm{C}$ is sufficient to induce the synthesis of $\mathrm{ClpB}$ protein.

Although the majority of temperature-dependent loci identified in this study were not associated directly with the virulence of $P$. atrosepticum, it is still possible that other unidentified bacterial loci could be implicated in its virulence. Forty transposon mutants of $P$. atrosepticum SCRI1043 were tested to investigate whether mutations in the identified genetic loci affected their phenotypic characteristics associated with the ability to cause potato tuber maceration. The majority of mutations in temperature-responsive loci did not have any noticeable effect on the phenotypes of the P. atrosepticum Tn5 mutants. Only five thermoresponsive transposon mutants of P. atrosepticum SCRI1043 displayed discriminative phenotypes (e.g., low maceration ability, decreased biofilm formation, lack of PCWDE activities) from the phenotype of the wild-type P. atrosepticum strain SCRI1043:

Mutant PbaTn5-B76: had a mutation in the region, homologous to the gall gene encoding UTP-glucose-1-phosphate uridylyltransferase, which catalyzes the formation of UDP-glucose from glucose-1-phosphate and UTP [74]. In E. coli, UDP-glucose is an essential intermediate for growth on galactose and trehalose and is involved in the biosynthesis of carbohydrates [75]. Mutation in the gall gene reduced the virulence of many bacterial pathogens, for instance, E. coli [76], P. aeruginosa [77], P. syringae [78], Vibrio cholerae [79], X. citri subsp. citri [80], and the secretion of $\alpha$-hemolysin and $D$. dadantii protease expression in E. coli [81]. These defects in virulence and secretion might be a consequence of the defect in lipopolysaccharide [81]. This study showed that the expression of the gall gene had a 1.6-fold increase at $18{ }^{\circ} \mathrm{C}$ compared to $28^{\circ} \mathrm{C}$. This finding is in line with the results of White-Ziegler et al. [68], which showed that a lower temperature $\left(23^{\circ} \mathrm{C}\right)$ increases the expression of the gall gene in E. coli. This study found that the PbaTn5-B76 mutant showed reduced pectate lyase, cellulase, and protease activity and exhibited reduced virulence on potato tubers. It can be speculated that the galU mutant of $P$. atrosepticum produces the truncated LPS, which enhances the surface hydrophobicity of these mutants, which may have resulted in increased autoaggregation and enhanced biofilm formation.

For the mutant PbaTn5-A43, the possible association of identified mutated genetic locus with their ability to macerate plant tissue is not so straightforward. In this mutant, the transposon insertion has been localized in gene encoding protein, lacking homologs in the other bacterial species, explaining its function. The mutant PbaTn5-A43 displayed enhanced virulence on potato tuber slices compared to the wild-type strain. We can only hypothesize that this hypothetical protein could be involved in the pathogenesis of P. atrosepticum, but further experimental analysis is required to establish its ecological relevance.

Mutant PbaTn5-43 carried transposon insertion in the gene related to the biosynthesis of LPS. It was shown that the wba gene was up-regulated at $18^{\circ} \mathrm{C}$. The $\mathrm{WbaP}$ (formerly RfbP) protein is a UDP-phosphate galactose phosphotransferase involved in the synthesis of the core oligosaccharide and O-antigen [82]. The wba mutant of S. enterica produced LPS lacking full-length O-antigen [83]. Also, the mutants of Vibrio fischeri that contained a mutation in the gene encoding a putative undecaprenyl-phosphate galactose phosphotransferase had an increased biofilm formation ability [84].

Mutant PbaTn5-B58: carried transposon insertion in the gene related to the biosynthesis of EPS. In this study, the wza gene was shown to be up-regulated at $28{ }^{\circ} \mathrm{C}$. Many bacteria produce EPS and capsular polysaccharides (CPS) that play crucial roles during the infection process in human and animal pathogens [85]. In plant pathogenic bacteria, the production of EPS on plant surfaces or tissues allows bacterial colonization and biofilm formation [86]. Wza is an outer membrane lipoprotein of the outer membrane auxiliary (OMA) family of proteins, which is essential for the export and assembly of CPS and EPS in E. coli $[85,87]$. In this study, the wza mutant in PbaTn5-B58 exhibited an increased biofilm formation on polypropylene surfaces as well as displaying a decreased growth rate on M9 minimal medium supplemented with $0.4 \%$ glycerol. These results are consistent with those of Yi et al. [88], who showed that the wza deficient mutant of Riemerella anatipestifer grew slowly, had a significantly increased biofilm formation capacity, and exhibited en- 
hanced autoaggregation compared to the wild-type strain. It is possible that the increased hydrophobicity of the wza mutant may affect the increased biofilm formation capacity [88]. On the contrary, a different study showed that transposon mutants of Klebsiella pneumoniae with insertions in $w z a$ locus were deficient in biofilm formation [89].

Mutant PbaTn5-B31: inactivation of the gene rbsK responsible for the ribokinase synthesis demonstrated a reduction in biofilm formation compared to the wild-type strain. Ribokinase (RbsK) catalyzes the conversion of ribose to ribose 5-phosphate [90,91]. The $r b s K$ gene is part of the rbs operon, which also involves the high-affinity ribose transport system [91]. Following the present result, the previous study has demonstrated that the rbsK mutant of E. coli showed a two-fold decrease in the level of biofilm formation compared to the wild-type [92]. Also, the rbsK gene of S. aureus was found to be downregulated in a biofilm in comparison to the stationary phase of planktonic growth [93]. Furthermore, the observed phenotype of this mutant could result from polar effect on the downstream $r b s R$ gene encoding the repressor of the ribose operon, which was confirmed for the $r b s K$ mutant of Serratia sp. [94].

Of the 29 temperature-regulated P. atrosepticum loci in detail characterized in this study, 14 were predicted to be expressed as parts of the operons, whereas 15 others were expected to be transcribed as single genes. The knowledge of the molecular basis of P. atrosepticum temperature-regulated gene expression is scarce. As the genes arranged in operons are in the majority functionally related to each other and/or regulated in a sequential manner, it is interesting to see that in P. atrosepticum SCRI1043, at least some of them, as demonstrated in this study, are also differentially expressed according to the temperature.

The obtained result indicated that several loci essential for the virulence of $P$. atrosepticum were identified. Further analysis of these genes will improve our knowledge about temperature-dependent mechanisms important for these plant-pathogenic bacteria during disease development. Future research could reveal the functions of these genes in the ecology and pathogenicity of this pathogen. However, it can be speculated that the temperature-induced loci identified in this study may also play a role in the ecological adaptation and fitness of P. atrosepticum and may also favor the survival of bacteria in unfavorable environmental conditions. It is important to note that many of the differentially regulated genes in response to the temperature code for hypothetical proteins that have an unknown function, and thereby these hypothetical proteins may possess novel physiological roles associated with thermoregulation.

\section{Materials and Methods}

\subsection{Bacterial Strains and Media Used}

P. atrosepticum SCRI1043 was grown at $28^{\circ} \mathrm{C}$ with aeration $(140 \mathrm{rpm})$ in tryptic soy broth (TSB; Oxoid, Basingstoke, UK) or in M9 minimal medium (MP Biomedicals, Thüringen, Germany) prepared as described by Czajkowski et al. [61] containing $2 \mathrm{mM}$ magnesium sulfate (Sigma-Aldrich, Darmstadt, Germany), $0.1 \mathrm{mM}$ calcium chloride (Sigma-Aldrich, Darmstadt, Germany), and 0.4\% glucose (Sigma-Aldrich, Darmstadt, Germany) as a carbon source, $\mathrm{pH}$ 7. To solidify the media, $15 \mathrm{~g} \mathrm{~L}^{-1}$ agar (Oxoid, Basingstoke, UK) was added. Escherichia coli S17-1 $\lambda$-pir strain carrying plasmid pCAM140 with mini-Tn5 transposon [64] was cultured with aeration (120 rpm) in TSB or on tryptic soy agar (TSA; Oxoid, Basingstoke, UK) supplemented with ampicillin (Sigma-Aldrich, Darmstadt, Germany) to a final concentration of $100 \mu \mathrm{g} \mathrm{mL}-1$ at $37^{\circ} \mathrm{C}$. When required, the bacterial media were supplemented with streptomycin (Sigma-Aldrich, Darmstadt, Germany) to a final concentration of $50 \mu \mathrm{g} \mathrm{mL}^{-1}$ and with X-Gluc (5-bromo-4-chloro-3-indolyl- $\beta$-D-glucuronic acid; GeneON, Ludwigshafen am Rhein, Germany) to a final concentration of $20 \mu \mathrm{g} \mathrm{mL}{ }^{-1}$. For long-term usage, bacterial strains were stored in $40 \%(v / v)$ glycerol at $-80^{\circ} \mathrm{C}$.

\subsection{Transposon Mutagenesis of P. atrosepticum SCRI1043}

Random transposon mutagenesis by mini-Tn 5 transposon was carried out by conjugation of $P$. atrosepticum strain SCRI1043 with E. coli S17- $1 \lambda$-pir containing pCAM140 at $28{ }^{\circ} \mathrm{C}$ 
as described previously [61,95]. Suicide plasmid pCAM140 harbors a mini-Tn5 transposon that has a promotorless $\beta$-glucuronidase gene (gusA). This plasmid can be replicated in E. coli S17-1 $\lambda$-pir but not in P. atrosepticum cells [64]. The efficiency of Tn5 transfer was defined as the ratio of the number of obtained mutants to the total number of recipient P. atrosepticum cells after $6 \mathrm{~h}$ of mating with a 1:1 ratio of donor to recipient. The experiment was independently repeated three times, and the results were averaged.

\subsection{Identification of P. atrosepticum Tn5 Mutants by PCR and Plating on Selective CVP Medium}

PCR detection of $P$. atrosepticum transposon mutants was performed using the previously described colony PCR procedure [61] according to Frechon et al. [96] using primers Y45 (5'-TCACCGGACGCCGAACTGTGGCGT-3', Genomed, Warsaw, Poland) and Y46 (5'-TCGCCAACGTTCAGCAGAACAAGT-3', Genomed, Warsaw, Poland). These primers amplify a $439 \mathrm{bp}$ fragment exclusively from strains of $P$. atrosepticum. The presence of transposon in P. atrosepticum SCRI1043 mutants was additionally confirmed by PCR using primers gusAf (5'-ACGTCCTGTAGAAACCCCAAC-3', Genomed, Warsaw, Poland) and gusAr (5'-TTGTCCAGTTGCAACCACCT-3', Genomed, Warsaw, Poland), which amplified a $679 \mathrm{bp}$ fragment of the gusA gene located in the miniTn5 transposon. Amplified DNA fragments were detected by electrophoresis on a $1 \% 0.5 \times$ TBE agarose gel stained with $50 \mu \mathrm{g} \mathrm{mL}{ }^{-1}$ GelRed (Biotium, Fremont, CA, USA). The ability of Tn5 mutants to form characteristic cavities (pits) specific for SRP on crystal violet pectate medium (CVP) was tested as described by Helias et al. [97].

\subsection{Visual Estimation of $\beta$-glucuronidase Activity of P. atrosepticum Tn5 Mutants}

The $\beta$-glucuronidase (GUS) activity of the Tn 5 bacterial mutants was estimated visually by the development of blue color of bacterial colonies growing at 18 and $28^{\circ} \mathrm{C}$ on M9 agar plates supplemented with streptomycin to a final concentration of $50 \mu \mathrm{g} \mathrm{mL}^{-1}$ and X-Gluc to a final concentration of $20 \mu \mathrm{g} \mathrm{mL}^{-1}$. Intensities of blue color formation were compared daily for a total time of 4 days. The experiment was independently repeated twice with the same setup. Mutants expressing the identical phenotypes at two selected temperatures (e.g., white at $18{ }^{\circ} \mathrm{C}$ and white at $28^{\circ} \mathrm{C}$ or blue at $18{ }^{\circ} \mathrm{C}$ and blue at $28^{\circ} \mathrm{C}$ ) were removed from further analyses.

\subsection{Semi-Quantitative Assays to Assess the Rate of Gene Expression in P. atrosepticum Tn5 Mutants}

The $\beta$-glucuronidase activity was quantified by a spectrophotometric assay with $\mathrm{p}$ nitrophenol- $\beta$-D-glucuronide (Sigma-Aldrich, Darmstadt, Germany) as a substrate for $\beta$ glucuronidase with following fluorometric assay using 4-methylumbelliferyl- $\beta$-D-glucuronide (Merck, Warsaw, Poland) as a substrate for $\beta$-glucuronidase as previously described [61]. Total protein concentration was determined using the Bradford method [98] with a Pierce BCA Protein Assay kit (Thermo Scientific, Warsaw, Poland). The $\beta$-glucuronidase activity of the Tn5 mutants was measured as a pmol product (p-nitrophenol or 4-methyl umbelliferone) per min per $\mu g$ total protein. Mutants showing statistically significant differences in $\beta$-glucuronidase activity at either temperature were selected and retested under the same conditions with four replicates per isolate and used in the follow-up studies.

\subsection{Identification of Regions Flanking the Tn5 Transposon Insertion}

Genomic DNA from P. atrosepticum transposon mutants was isolated according to procedures described by Sambrook et al. [99]. The flanking sequences of the insertion site were obtained by sequencing from the O-end and I-end of the miniTn5 with the primers OendB 5'-TTTCTACAGGACGTAACATAAGGG-3' [100] and IendB 5'GGGAATTCGGCCTAGGCGG-3' [101]. DNA sequencing was performed at the Laboratory of DNA Sequencing and Oligonucleotide Synthesis at the Institute of Biochemistry and Biophysics of the Polish Academy of Science, Warsaw, Poland. Obtained sequences were compared with available sequences of bacterial genes deposited in GenBank using the 
BLASTN and BLASTX alignments (https://blast.ncbi.nlm.nih.gov/Blast.cgi, accessed: January-July 2018).

\subsection{Phenotypic Characterization of P. atrosepticum Transposon Mutants}

P. atrosepticum $\mathrm{Tn} 5$ transposon mutants that showed at least 1.5 -fold-increased GUS activity in a temperature-dependent manner were characterized further for their ability to swim on motility agar [102], to produce pectate lyases [103], cellulases [104], proteases [105], ability to form a biofilm [106] and to cause rotting of potato tubers [107]. The phenotypic tests were done at $28^{\circ} \mathrm{C}$.

\subsection{Measurement of Bacterial Growth Rates}

Growth rates of P. atrosepticum transposon mutants were measured using EnVision Multilabel Reader (Perkin Elmer, Baesweiler, Germany). Overnight bacterial cultures, grown at $28{ }^{\circ} \mathrm{C}$, were diluted at 1:50 with fresh M9 medium supplemented with $0.4 \%$ glucose or $0.4 \%$ glycerol, and $0.5 \mathrm{~mL}$ of the diluted culture was added to the internal wells of 48-well microtiter plates (Becton Dickinson Labware, Temse, Belgium). Plates were sealed using optical clear sealing tape (Sarstedt, Warsaw, Poland) and incubated at $28^{\circ} \mathrm{C}$ with shaking (orbital, $60 \mathrm{rpm}$ ). The growth was recorded spectrophotometrically at $600 \mathrm{~nm}$ wavelength every hour for the total incubation time of $16 \mathrm{~h}$. The growth of each $P$. atrosepticum transposon mutant was analyzed in six replicates, and the results were averaged per strain. Each 48-well plate contained six negative (non-inoculated growth medium) and six positive (wild-type P. atrosepticum SCRI1043 culture) wells as controls. A Growthcurver package in R [108] was used to calculate growth rates and the generation (doubling) time. The experiment was independently repeated once with the same setup.

\subsection{LPS Extraction and Analysis}

Crude lipopolysaccharides (LPS) were extracted from an equivalent number of bacterial cells (5 McF), as described by Apicella et al. [109]. Samples were analyzed using NuPAGE $^{\mathrm{TM}} 4-12 \%$ Bis-Tris gels (1.0 mm, 12-well) and the corresponding NuPAGE MOPS SDS running buffer $(20 \times)$ from Thermo Scientific, Warsaw, Poland. Silver staining was performed as described by Tsai and Frasch [110].

4.10. Morphological Characterization of the P. atrosepticum SCRI1043 Tn5 Mutants by Electron Microscopy (TEM)

Bacteria were grown overnight in TSB at $28^{\circ} \mathrm{C}$ with shaking $(200 \mathrm{rpm})$. TEM analysis was performed by the Laboratory of Electron Microscopy (Faculty of Biology, University of Gdansk, Poland). For the TEM analysis, bacteria were adsorbed onto carbon-coated grids (Sigma-Aldrich, Darmstadt, Germany), stained with 1.5\% uranyl acetate, and directly examined with an electron microscope (Tecnai Spirit BioTWIN, FEI, New York, NY, USA) as described by Czajkowski et al. [111]. At least 10 photos were taken per strain to assess the morphology of $\operatorname{Tn} 5$ bacterial mutants.

\subsection{Time-Dependent Induction of Gene Expression in Tn5 Mutants}

Bacterial cultures of P. atrosepticum transposon mutants were cultivated in liquid in $30 \mathrm{~mL} \mathrm{M9} \mathrm{minimal} \mathrm{medium} \mathrm{supplemented} \mathrm{with} 0.4 \%$ glucose at the respective noninductive temperature in the incubator with temperature control and shaking (140 rpm) until the cell density reached an OD600 of 1.0. Afterwards, the bacterial cultures were shifted to the growth temperature known to induce GUS activity in the respective mutant. Samples were taken at 1-2 $\mathrm{h}$ intervals for the total time of $9 \mathrm{~h}$ after the shift, and GUS activity was measured using the fluorometric GUS assay.

\subsection{Statistical Analysis}

Statistical analysis of data was performed using the R software [112]. At least two independent biological replicates were analyzed in each experiment. Error bars in the 
figures indicate standard deviation. Levene's test [113] was applied for testing the equality of variances, and Shapiro-Wilk's test [114] was implemented for evaluating the normality of the data. A Student's t-test was performed to determine whether there was a significant difference in the different phenotypes between the wild-type and the transposon mutants. Significance was defined as a $p$-value lower than 0.05. The Wilcoxon-Mann-Whitney test [115] was used instead of a $t$-test when the data were not normally distributed.

Supplementary Materials: The following are available online at https:/ /www.mdpi.com/article/10 $.3390 /$ ijms22094839/s1.

Author Contributions: Conceptualization, R.C. and N.K.; methodology, R.C., N.K.; software, N.K., M.N.; validation, N.K., R.C.; formal analysis, R.C.; investigation, N.K.; resources, R.C.; data curation, N.K., R.C.; writing-original draft preparation, N.K., E.L., R.C.; writing-review and editing, N.K., R.C.; visualization, N.K., M.N.; supervision, R.C., E.L.; project administration, R.C.; funding acquisition, R.C. All authors have read and agreed to the published version of the manuscript.

Funding: This research was funded by the Ministry of Science and Higher Education, Poland (Ministerstwo Nauki i Szkolnictwa Wyzszego, Polska) via a research grant Iuventus Plus 2012 (0241/IP1/2013/72) to R.C. and co-funded from Norway Grants in the Polish-Norwegian Research Programme operated by the National Centre for Research and Development grant POTPAT (no. Pol-Nor/202448/28/2013: Work Package 1) to R.C.

Institutional Review Board Statement: Not applicable.

Informed Consent Statement: Not applicable.

Data Availability Statement: Data are contained within the article and supplementary material.

Conflicts of Interest: The authors declare no conflict of interest. The funders had no role in the design of the study; in the collection, analyses, or interpretation of data; in the writing of the manuscript, or in the decision to publish the results.

\section{References}

1. FAOSTAT. Available online: http://www.fao.org/faostat/en/\#data/QC (accessed on 30 March 2021).

2. Perombelon, M.C.M. Potato diseases caused by soft rot Erwinias: An overview of pathogenesis. Plant Pathol. 2002, 51, 1-12. [CrossRef]

3. Czajkowski, R.; Grabe, G.J.; van der Wolf, J.M. Distribution of Dickeya spp. and Pectobacterium carotovorum subsp. carotovorum in naturally infected seed potatoes. Eur. J. Plant Pathol. 2009, 125, 263-275. [CrossRef]

4. Toth, I.K.; van der Wolf, J.M.; Saddler, G.; Lojkowska, E.; Helias, V.; Pirhonen, M.; Tsror (Lahkim), L.; Elphinstone, J.G. Dickeya species: An emerging problem for potato production in Europe. Plant Pathol. 2011, 60, 385-399. [CrossRef]

5. Gardan, L.; Gouy, C.; Christen, R.; Samson, R. Elevation of three subspecies of Pectobacterium carotovorum to species level: Pectobacterium atrosepticum sp. nov., Pectobacterium betavasculorum sp. nov. and Pectobacterium wasabiae sp. nov. Int. J. Syst. Evol. Microbiol. 2003, 53, 381-391. [CrossRef] [PubMed]

6. Khayi, S.; Cigna, J.; Chong, T.M.; Quetu-Laurent, A.; Chan, K.-G.; Helias, V.; Faure, D. Transfer of the potato plant isolates of Pectobacterium wasabiae to Pectobacterium parmentieri sp. nov. Int. J. Syst. Evol. Microbiol. 2016, 66, 5379-5383. [CrossRef] [PubMed]

7. Dees, M.W.; Lysøe, E.; Rossmann, S.; Perminow, J.; Brurberg, M.B. Pectobacterium polaris sp. nov., isolated from potato (Solanum tuberosum). Int. J. Syst. Evol. Microbiol. 2017, 67, 5222-5229. [CrossRef]

8. Sarfraz, S.; Riaz, K.; Oulghazi, S.; Cigna, J.; Sahi, S.T.; Khan, S.H.; Faure, D. Pectobacterium punjabense sp. nov., isolated from blackleg symptoms of potato plants in Pakistan. Int. J. Syst. Evol. Microbiol. 2018, 68, 3551-3556. [CrossRef] [PubMed]

9. Pedron, J.; Bertrand, C.; Taghouti, G.; Portier, P.; Barny, M.A. Pectobacterium aquaticum sp. nov., isolated from waterways. Int. J. Syst. Evol. Microbiol. 2019, 69, 745-751. [CrossRef] [PubMed]

10. Portier, P.; Pédron, J.; Taghouti, G.; Fischer-Le Saux, M.; Caullireau, E.; Bertrand, C.; Laurent, A.; Chawki, K.; Oulgazi, S.; Moumni, M.; et al. Elevation of Pectobacterium carotovorum subsp. odoriferum to species level as Pectobacterium odoriferum sp. nov., proposal of Pectobacterium brasiliense sp. nov. and Pectobacterium actinidiae sp. nov., emended description of Pectobacterium carotovorum and description of Pectobacterium versatile sp. nov., isolated from streams and symptoms on diverse plants. Int. J. Syst. Evol. Microbiol. 2019, 69, 3207-3216.

11. Waleron, M.; Misztak, A.; Waleron, M.; Franczuk, M.; Wielgomas, B.; Waleron, K. Transfer of Pectobacterium carotovorum subsp. carotovorum strains isolated from potatoes grown at high altitudes to Pectobacterium peruviense sp. nov. Syst. Appl. Microbiol. 2018, 41, 85-93. [CrossRef]

12. Waleron, M.; Misztak, A.; Waleron, M.; Jonca, J.; Furmaniak, M.; Waleron, K. Pectobacterium polonicum sp. nov. isolated from vegetable fields. Int. J. Syst. Evol. Microbiol. 2019, 69, 1751-1759. [CrossRef] [PubMed] 
13. Pasanen, M.; Waleron, M.; Schott, T.; Cleenwerck, I.; Misztak, A.; Waleron, K.; Pritchard, L.; Bakr, R.; Degefu, Y.; van der Wolf, J.; et al. Pectobacterium parvum sp. nov., having a Salmonella SPI-1-like type III secretion system and low virulence. Int. J. Syst. Evol. Microbiol. 2020, 70, 2440-2448. [CrossRef] [PubMed]

14. Samson, R.; Legendre, J.B.; Christen, R.; Fischer-Le Saux, M.; Achouak, W.; Gardan, L. Transfer of Pectobacterium chrysanthemi (Burkholder et al. 1953) Brenner et al. 1973 and Brenneria paradisiaca to the genus Dickeya gen. nov. as Dickeya chrysanthemi comb. nov. and Dickeya paradisiaca comb. nov. and delineation of four novel species, Dickeya dadantii sp. nov., Dickeya dianthicola sp. nov, Dickeya dieffenbachiae sp. nov. and Dickeya zeae sp. nov. Int. J. Syst. Evol. Microbiol. 2005, 55, 1415-1427.

15. Parkinson, N.; DeVos, P.; Pirhonen, M.; Elphinstone, J. Dickeya aquatica sp. nov., isolated from waterways. Int. J. Syst. Evol. Microbiol. 2014, 64, 2264-2266. [CrossRef] [PubMed]

16. van der Wolf, J.M.; Nijhuis, E.H.; Kowalewska, M.J.; Saddler, G.S.; Parkinson, N.; Elphinstone, J.G.; Pritchard, L.; Toth, I.K.; Lojkowska, E.; Potrykus, M.; et al. Dickeya solani sp. nov., a pectinolytic plant-pathogenic bacterium isolated from potato (Solanum tuberosum). Int. J. Syst. Evol. Microbiol. 2014, 64, 768-774. [CrossRef] [PubMed]

17. Toth, I.K.; Barny, M.; Czajkowski, R.; Elphinstone, J.G.; Li, X.; Pédron, J.; Pirhonen, M.; Van Gijsegem, F. Pectobacterium and Dickeya: Taxonomy and evolution. In Plant Diseases Caused by Dickeya and Pectobacterium Species; Van Gijsegem, F., van der Wolf, J.M., Toth, I.K., Eds.; Springer International Publishing: Cham, Switzerland, 2021; pp. 13-37.

18. Mansfield, J.; Genin, S.; Magori, S.; Citovsky, V.; Sriariyanum, M.; Ronald, P.; Dow, M.; Verdier, V.; Beer, S.V.; Machado, M.A.; et al. Top 10 Plant Pathogenic Bacteria in Molecular Plant Pathology. Mol. Plant Pathol. 2012, 13, 614-629. [CrossRef]

19. Perombelon, M.C.M.; Kelman, A. Ecology of the soft rot Erwinias. Annu. Rev. Phytopathol. 1980, 18, 361-387. [CrossRef]

20. Cother, E.J.; Gilbert, R.L. Presence of Erwinia chrysanthemi in two major river systems and their alpine sources in Australia. J. Appl. Bacteriol. 1990, 69, 729-738. [CrossRef]

21. Laurila, J.; Hannukkala, A.; Nykyri, J.; Pasanen, M.; Hélias, V.; Garlant, L.; Pirhonen, M. Symptoms and yield reduction caused by Dickeya spp. strains isolated from potato and river water in Finland. Eur. J. Plant Pathol. 2010, 126, 249-262. [CrossRef]

22. Tsror (Lahkim), L.; Lebiush, S.; Erlich, O.; Ben-Daniel, B.; van der Wolf, J. First report of latent infection of Cyperus rotundus cused by a biovar 3 Dickeya sp. (syn. Erwinia chrysanthemi) in Israel. New Dis. Rep. 2010, 22, 14. [CrossRef]

23. Potrykus, M.; Golanowska, M.; Sledz, W.; Zoledowska, S.; Motyka, A.; Kolodziejska, A.; Butrymowicz, J.; Lojkowska, E. Biodiversity of Dickeya spp. isolated from potato plants and water sources in temperate climate. Plant Dis. 2016, 100, 408-417. [CrossRef] [PubMed]

24. Fikowicz-Krosko, J.; Wszalek-Rozek, K.; Smolarska, A.; Czajkowski, R. First report on isolation of soft rot Pectobacterium carotovorum subsp. carotovorum from symptomless bittersweet nightshade occurring in rural area in Poland. J. Plant Pathol. 2017, 99, 294.

25. Pulatov, B.; Linderson, M.L.; Hall, K.; Jönsson, A.M. Modeling climate change impact on potato crop phenology, and risk of frost damage and heat stress in northern Europe. Agric. For. Meteorol. 2015, 214, 281-292. [CrossRef]

26. du Raan, S.; Coutinho, T.A.; van der Waals, J.E. Cardinal temperature differences, determined in vitro, between closely related species and subspecies of pectinolytic bacteria responsible for blackleg and soft rot on potatoes. Eur. J. Plant Pathol. 2016, 144, 361-369. [CrossRef]

27. Golanowska, M.; Kielar, J.; Lojkowska, E. The effect of temperature on phenotypic features and the maceration ability of Dickeya solani strains isolated in Finland, Israel and Poland. Eur. J. Plant Pathol. 2017, 147, 803-817. [CrossRef]

28. Janse, J.D.; Ruissen, M.A. Characterization and classification of Erwinia chrysanthemi strains from several osts in the Netherlands. Phytopathology 1988, 78, 800-808. [CrossRef]

29. Cazelles, O.; Schwärzel, R. Survey of bacterial diseases caused by Erwinia in seed potato fields in western Switzerland. Rev. Suisse d'Agric. 1992, 24, 215-218.

30. Degefu, Y.; Potrykus, M.; Golanowska, M.; Virtanen, E.; Lojkowska, E. A new clade of Dickeya spp. plays a major role in potato blackleg outbreaks in north Finland. Ann. Appl. Biol. 2013, 162, 231-241. [CrossRef]

31. Motyka, A.; Zoledowska, S.; Sledz, W.; Lojkowska, E. Molecular methods as tools to control plant diseases caused by Dickeya and Pectobacterium spp: A minireview. New Biotechnol. 2017, 39, 181-189. [CrossRef]

32. Tsror (Lahkim), L.; Erlich, O.; Lebiush, S.; van der Wolf, J.; Czajkowski, R.; Mozes, G.; Sikharulidze, Z.; Ben-Daniel, B. First report of potato blackleg caused by a biovar 3 Dickeya sp. in Georgia. New Dis. Rep. 2011, 23, 1. [CrossRef]

33. Ignatov, A.N.; Karlov, A.N.; Dzhalilov, F.S. Spreading of the blackleg of potatoes in Russia caused by bacteria of Dickeya genus. Zaschita Karantin Rastenij 2014, 11, 41-43.

34. de Werra, P.; Bussereau, F.; Kellenberger, I.; Dupuis, B.; Schaerer, S.; Keiser, A. Potato: The Pectobacterium empire strikes back. Agrar. Schweiz 2015, 6, 256-263.

35. van der Wolf, J.M.; de Haan, E.G.; Kastelein, P.; Krijger, M.; de Haas, B.H.; Velvis, H.; Mendes, O.; Kooman-Gersmann, M.; van der Zouwen, P.S. Virulence of Pectobacterium carotovorum subsp. brasiliense on potato compared with that of other Pectobacterium and Dickeya species under climatic conditions prevailing in the Netherlands. Plant Pathol. 2017, 66, 571-583. [CrossRef]

36. Zoledowska, S.; Motyka, A.; Zukowska, D.; Sledz, W.; Lojkowska, E. Population structure and biodiversity of Pectobacterium parmentieri isolated from potato fields in temperate climate. Plant Dis. 2018, 102, 154-164. [CrossRef]

37. Oulghazi, S.; Sarfraz, S.; Zaczek-Moczydłowska, M.A.; Khayi, S.; Ed-Dra, A.; Lekbach, Y.; Campbell, K.; Moleleki, L.N.; O’hanlon, R.; Faure, D. Pectobacterium brasiliense: Genomics, host range and disease management. Microorganisms 2021, 9, 106. [CrossRef] 
38. Śledź, W.; Jafra, S.; Waleron, M.; Łojkowska, E. Genetic diversity of Erwinia carotovora strains isolated from infected plants grown in Poland. Bull. OEPP/EPPO Bull. 2000, 30, 403-407. [CrossRef]

39. Dees, M.W.; Lebecka, R.; Perminow, J.I.S.; Czajkowski, R.; Grupa, A.; Motyka, A.; Zoledowska, S.; Sliwka, J.; Lojkowska, E.; Brurberg, M.B. Characterization of Dickeya and Pectobacterium strains obtained from diseased potato plants in different climatic conditions of Norway and Poland. Eur. J. Plant Pathol. 2017, 148, 839-851. [CrossRef]

40. Skelsey, P.; Humphris, S.N.; Campbell, E.J.; Toth, I.K. Threat of establishment of non-indigenous potato blackleg and tuber soft rot pathogens in Great Britain under climate change. PLoS ONE 2018, 13, e0205711. [CrossRef] [PubMed]

41. van der Wolf, J.M.; Acuña, I.; De Boer, S.H.; Brurberg, M.B.; Cahill, G.; Charkowski, A.O.; Coutinho, T.; Davey, T.; Dees, M.W.; Degefu, Y.; et al. Diseases caused by Pectobacterium and Dickeya species around the world. In Plant Diseases Caused by Dickeya and Pectobacterium Species; Van Gijsegem, F., van der Wolf, J.M., Toth, I.K., Eds.; Springer International Publishing: Cham, Switzerland, 2021; pp. 215-261.

42. Zaczek-Moczydłowska, M.A.; Fleming, C.C.; Young, G.K.; Campbell, K.; O’Hanlon, R. Pectobacterium and Dickeya species detected in vegetables in Northern Ireland. Eur. J. Plant Pathol. 2019, 154, 635-647. [CrossRef]

43. Perombelon, M.C.M. Potato blackleg: Epidemiology, host-pathogen interaction and control. Neth. J. Plant Pathol. 1992, 98, 135-146. [CrossRef]

44. Stommel, J.R.; Goth, R.W.; Haynes, K.G.; Kim, S.H. Pepper (Capsicum annum) soft rot caused by Erwinia carotovora subsp. atroseptica. Plant Dis. 1996, 80, 1109-1112. [CrossRef]

45. Baştaş, K.K.; Hekimhan, H.; Maden, S.; Tör, M. First report of bacterial stalk and head rot disease caused by Pectobacterium atrosepticum on sunflower in Turkey. Plant Dis. 2009, 93, 1352. [CrossRef] [PubMed]

46. Ma, B.; Hibbing, M.E.; Kim, H.; Reedy, R.M.; Yedidia, I.; Breuer, J.; Breuer, J.; Glasner, J.D.; Perna, N.T.; Kelman, A.; et al. Host range and molecular phylogenies of the soft rot Enterobacterial genera Pectobacterium and Dickeya. Phytopathology 2007, 97, 1150-1163. [CrossRef] [PubMed]

47. Glasner, J.D.; Kim, H.; Jahn, C.E.; Ma, B.; Biehl, B.S.; Rissman, A.I.; Mole, B.; Yi, X.; Yang, C.; Dangl, J.L.; et al. Niche-specificity and the variable fraction of the Pectobacterium pan-genome. MPMI 2008, 21, 1549-1560. [CrossRef]

48. De Boer, S.H.; Li, X.; Ward, L.J. Pectobacterium spp. associated with bacterial stem rot syndrome of potato in Canada. Phytopathology 2012, 102, 937-947. [CrossRef]

49. Molina, J.J.; Harrison, M.D. The role of Erwinia carotovora in the epidemiology of potato blackleg. II. The effect of soil temperature on disease severity. Am. Potato J. 1980, 57, 351-363. [CrossRef]

50. Ali, H.F.; Ahmad, M.; Junaid, M.; Bibi, A.; Ali, A.; Sharif, M.; Ali, B.; Nawab, K.; Sadozai, A. Inoculum sources, disease incidence and severity of bacterial blackleg and soft rot of potato. Pak. J. Bot. 2012, 44, 825-830.

51. Czajkowski, R.; De Boer, W.J.; Van der Zouwen, P.S.; Kastelein, P.; Jafra, S.; De Haan, E.G.; van den Bovenkamp, G.W.; van der Wolf, J.M. Virulence of "Dickeya solani" and Dickeya dianthicola biovar-1 and -7 strains on potato (Solanum tuberosum). Plant Pathol. 2013, 62, 597-610. [CrossRef]

52. Hugouvieux-Cotte-Pattat, N.; Dominguez, H.; Robert-Baudouy, J. Environmental conditions affect transcription of the pectinase genes of Erwinia chrysanthemi 3937. J. Bacteriol. 1992, 174, 7807-7818. [CrossRef]

53. Wei, Z.; Sneath, B.J.; Beer, S.V. Expression of Erwinia amylovora hrp genes in response to environmental stimuli. J. Bacteriol. 1992, 174, 1875-1882. [CrossRef]

54. Ullrich, M.; Pen, A.; Bailey, A.; Bender, C.L. A modified two-component regulatory system is involved in temperature-dependent biosynthesis of the Pseudomonas syringae phytotoxin coronatine. J. Bacteriol. 1995, 177, 6160-6169. [CrossRef] [PubMed]

55. van Dijk, K.; Fouts, D.E.; Rehm, A.H.; Hill, A.R.; Collmer, A.; Alfano, J.R. The Avr (effector) proteins HrmA (HopPsyA) and AvrPto are secreted in culture from Pseudomonas syringae pathovars via the Hrp (Type III) protein secretion system in a temperature- and pH-sensitive manner. J. Bacteriol. 1999, 181, 4790-4797. [CrossRef] [PubMed]

56. Smirnova, A.; Li, H.; Weingart, H.; Aufhammer, S.; Burse, A.; Finis, K.; Schenk, A.; Ullrich, M.S. Thermoregulated expression of virulence factors in plant-associated bacteria. Arch. Microbiol. 2001, 176, 393-399. [CrossRef] [PubMed]

57. Smadja, B.; Latour, X.; Trigui, S.; Burini, J.F.; Chevalier, S.; Orange, N. Thermodependence of growth and enzymatic activities implicated in pathogenicity of two Erwinia carotovora subspecies (Pectobacterium spp.). Can. J. Microbiol. 2004, 50, 19-27. [CrossRef] [PubMed]

58. Lanham, P.G.; Mcllravey, K.I.; Perombelon, M.C.M. Production of cell wall dissolving enzymes by Erwinia carotovora subsp. atroseptica in vitro at $27^{\circ} \mathrm{C}$ and $30.5^{\circ} \mathrm{C}$. J. Appl. Bacteriol. 1991, 70, 20-24. [CrossRef]

59. Ullrich, M.S.; Schergaut, M.; Boch, J.; Ullrich, B. Temperature-responsive genetic loci in the plant pathogen Pseudomonas syringae pv. glycinea. Microbiology 2000, 146, 2457-2468. [CrossRef] [PubMed]

60. Goyer, C.; Ullrich, M.S. Identification of low-temperature-regulated genes in the fire blight pathogen Erwinia amylovora. Can. J. Microbiol. 2006, 52, 468-475. [CrossRef]

61. Czajkowski, R.; Kaczyńska, N.; Jafra, S.; Narajczyk, M.; Lojkowska, E. Temperature-responsive genetic loci in pectinolytic plant pathogenic Dickeya solani. Plant Pathol. 2017, 66, 584-594. [CrossRef]

62. Hinton, J.C.D.; Sidebotham, J.M.; Hyman, L.J.; Prombdon, M.C.M.; Salmond, G.P.C. Isolation and characterisation of transposoninduced mutants of Erwinia carotovora subsp. atroseptica exhibiting reduced virulence. Mol. Gen. Genet. 1989, 217, 141-148. [CrossRef] 
63. Bell, K.S.; Sebaihia, M.; Pritchard, L.; Holden, M.T.G.; Hyman, L.J.; Holeva, M.C.; Thomson, N.R.; Bentley, S.D.; Churcher, L.J.C.; Mungall, K.; et al. Genome sequence of the enterobacterial phytopathogen Erwinia carotovora subsp. atroseptica and characterization of virulence factors. Proc. Natl. Acad. Sci. USA 2004, 101, 11105-11110. [CrossRef] [PubMed]

64. Wilson, K.J.; Sessitsch, A.; Corbo, J.C.; Giller, K.E.; Akkermans, D.L.; Jefferson, R. Beta-glucuronidase (Gus) transposons for ecological and genetic-studies of Rhizobia and other gram-negative bacteria. Microbiology 1995, 141, 1691-1705. [CrossRef]

65. Huerta-Cepas, J.; Szklarczyk, D.; Heller, D.; Hernández-Plaza, A.; Forslund, S.K.; Cook, H.; Mende, D.R.; Letunic, I.; Rattei, T.; Jensen, L.J.; et al. EggNOG 5.0: A hierarchical, functionally and phylogenetically annotated orthology resource based on 5090 organisms and 2502 viruses. Nucleic Acids Res. 2019, 47, D309-D314. [CrossRef] [PubMed]

66. Haverkort, A.J.; Verhagen, A. Climate change and its repercussions for the potato supply chain. Potato Res. 2008, 51, $223-237$. [CrossRef]

67. Schaap, B.F.; Blom-Zandstra, M.; Hermans, C.M.L.; Meerburg, B.G.; Verhagen, J. Impact changes of climatic extremes on arable farming in the north of the Netherlands. Reg. Environ. Chang. 2011, 11, 731-741. [CrossRef]

68. White-Ziegler, C.A.; Um, S.; Perez, N.M.; Berns, A.L.; Malhowski, A.J.; Young, S. Low temperature $\left(23^{\circ} \mathrm{C}\right)$ increases expression of biofilm-, cold-shock- and RpoS-dependent genes in Escherichia coli K-12. Microbiology 2008, 154, 148-166. [CrossRef] [PubMed]

69. Dersch, P.; Kneip, S.; Bremer, E. The nucleoid-associated DNA-binding protein H-NS is required for the efficient adaptation of Escherichia coli K-12 to a cold environment. Mol. Gen. Genet. 1994, 245, 255-259. [CrossRef]

70. White-Ziegler, C.A.; Davis, T.R. Genome-wide identification of H-NS-controlled, temperature-regulated genes in Escherichia coli K-12. J. Bacteriol. 2009, 191, 1106-1110. [CrossRef]

71. Nasser, W.; Faelen, M.; Hugouvieux-Cotte-Pattat, N.; Reverchon, S. Role of the nucleoid-associated protein H-NS in the synthesis of virulence factors in the phytopathogenic bacterium Erwinia chrysanthemi. MPMI 2001, 14, 10-20. [CrossRef] [PubMed]

72. Schirmer, E.C.; Glover, J.R.; Singer, M.A.; Lindquist, S. HSP100/Clp proteins: A common mechanism explains diverse functions. Trends Biochem. Sci. 1996, 21, 289-296. [CrossRef]

73. Chan, K.-G.; Priya, K.; Chang, C.; Yamin, A.; Rahman, A.; Tee, K.K.; Yin, W.-F. Transcriptome analysis of Pseudomonas aeruginosa PAO1 grown at both body and elevated temperatures. PeerJ 2016, 4, 1-19. [CrossRef] [PubMed]

74. Thoden, J.B.; Holden, H.M. The molecular architecture of glucose-1-phosphate uridylyltransferase. Protein Sci. 2007, 16, 432-440. [CrossRef]

75. Weissborn, A.C.; Liu, Q.; Rumley, M.K.; Kennedy, E.P. UTP: $\alpha$-D-glucose-1-phosphate uridylyltransferase of Escherichia coli: Isolation and DNA sequence of the gall Gene and purification of the enzyme. J. Bacteriol. 1994, 176, 2611-2618. [CrossRef] [PubMed]

76. Ho, T.D.; Waldor, M.K. Enterohemorrhagic Escherichia coli O157:H7 gal mutants are sensitive to bacteriophage P1 and defective in intestinal colonization. Infect. Immun. 2007, 75, 1661-1666. [CrossRef]

77. Priebe, G.P.; Dean, C.R.; Zaidi, T.; Meluleni, G.J.; Coleman, F.T.; Coutinho, Y.S.; Noto, M.J.; Urban, T.A.; Pier, G.B.; Goldberg, J.B. The galU gene of Pseudomonas aeruginosa is required for corneal infection and efficient systemic spread following pneumonia but not for infection confined to the lung. Infect. Immun. 2004, 72, 4224-4232. [CrossRef]

78. Deng, W.-L.; Lin, Y.-C.; Lin, R.-H.; Wei, C.-F.; Huang, Y.-C.; Peng, H.-L.; Huang, H.-C. Effects of gall mutation on Pseudomonas syringae-plant interactions. MPMI 2010, 23, 1184-1196. [CrossRef] [PubMed]

79. Nesper, J.; Lauriano, C.M.; Klose, K.E.; Kapfhammer, D.; Kraiß, A.; Reidl, J. Characterization of Vibrio cholerae O1 El Tor galU and galE mutants: Influence on lipopolysaccharide structure, colonization, and biofilm formation. Infect. Immun. 2001, 69, 435-445. [CrossRef] [PubMed]

80. Guo, Y.; Sagaram, U.S.; Kim, J.; Wang, N. Requirement of the galU gene for polysaccharide production by and pathogenicity and growth in planta of Xanthomonas citri subsp. citri. Appl. Environ. Microbiol. 2010, 76, 2234-2242. [CrossRef] [PubMed]

81. Wandersman, C.; Letoffe, S. Involvement of lipopolysaccharide in the secretion of Escherichia coli $\alpha$-haemolysin and Erwinia chrysanthemi proteases. Mol. Microbiol. 1993, 7, 141-150. [CrossRef]

82. Wang, L.E.I.; Reeves, P.R. Involvement of the galactosyl-1-phosphate transferase encoded by the Salmonella enterica rfbP gene in O-antigen subunit processing. J. Bacteriol. 1994, 176, 4348-4356. [CrossRef] [PubMed]

83. Kong, Q.; Yang, J.; Liu, Q.; Alamuri, P.; Roland, K.L.; Curtiss, R. Effect of deletion of genes involved in lipopolysaccharide core and O-antigen synthesis on virulence and immunogenicity of Salmonella enterica serovar typhimurium. Infect. Immun. 2011, 79, 4227-4239. [CrossRef]

84. Shibata, S.; Yip, E.S.; Quirke, K.P.; Ondrey, J.M.; Visick, K.L. Roles of the structural symbiosis polysaccharide (syp) genes in host colonization, biofilm formation, and polysaccharide biosynthesis in Vibrio fischeri. J. Bacteriol. 2012, 194, 6736-6747. [CrossRef] [PubMed]

85. Cuthbertson, L.; Mainprize, I.L.; Naismith, J.H.; Whitfield, C. Pivotal roles of the outer membrane polysaccharide export and polysaccharide copolymerase protein families in export of extracellular polysaccharides in gram-negative bacteria. Microbiol. Mol. Biol. Rev. 2009, 73, 155-177. [CrossRef] [PubMed]

86. Bogino, P.C.; Oliva, M.; de las, M.; Sorroche, F.G.; Giordano, W. The role of bacterial biofilms and surface components in plant-bacterial associations. Int. J. Mol. Sci. 2013, 14, 15838-15859. [CrossRef] 
87. Dong, C.; Beis, K.; Nesper, J.; Brunkan-LaMontagne, A.L.; Clarke, B.R.; Whitfield, C.; Naismith, J.H. Wza the translocon for E. coli capsular polysaccharides defines a new class of membrane protein. Nature 2006, 444, 226-229. [CrossRef] [PubMed]

88. Yi, H.; Yuan, B.; Liu, J.; Zhu, D.; Wu, Y.; Wang, M.; Jia, R.; Sun, K.; Yang, Q.; Chen, S.; et al. Identification of a wza-like gene involved in capsule biosynthesis, pathogenicity and biofilm formation in Riemerella anatipestifer. Microb. Pathog. 2017, 107, 442-450. [CrossRef] [PubMed]

89. Wu, M.-C.; Lin, T.-L.; Hsieh, P.-F.; Yang, H.-C.; Wang, J.-T. Isolation of genes involved in biofilm formation of a Klebsiella pneumoniae strain causing pyogenic liver abscess. PLoS ONE 2011, 6, e23500. [CrossRef] [PubMed]

90. Iida, A.; Harayama, S.; Iino, T.; Hazelbauer, G.L. Molecular cloning and characterization of genes required for ribose transport and utilization in Escherichia coli K-12. J. Bacteriol. 1984, 158, 674-682. [CrossRef] [PubMed]

91. Hope, J.N.; Bell, W.; Hermodson, M.A.; Groarkeg, J.M. Ribokinase from Escherichia coli K12. J. Biol. Chem. 1986, 261, 7663-7668. [CrossRef]

92. Romeo, T.; Wang, X.; Desplas, R.L. Novel Genes Involved in the Escherichia coli Biofilm Formation and Uses Thereof. US Patent Appl. Publ. No. US20050032093A1, 2005.

93. Beenken, K.E.; Dunman, P.M.; Mcaleese, F.; Macapagal, D.; Murphy, E.; Projan, S.J.; Blevins, J.S.; Smeltzer, M.S. Global gene expression in Staphylococcus aureus biofilms. J. Bacteriol. 2004, 186, 4665-4684. [CrossRef]

94. Lee, C.M.; Monson, R.E.; Adams, R.M.; Salmond, G.P.C. The LacI-family transcription factor, RbsR, is a pleiotropic regulator of motility, virulence, siderophore and antibiotic production, gas vesicle morphogenesis and flotation in Serratia. Front. Microbiol. 2017, 8, 1678. [CrossRef]

95. Czajkowski, R.; Krzyzanowska, D.; Karczewska, J.; Atkinson, S.; Przysowa, J.; Lojkowska, E.; Williams, P.; Jafra, S. Inactivation of AHLs by Ochrobactrum sp. A44 depends on the activity of a novel class of AHL acylase. Environ. Microbiol. Rep. 2011, 3, 59-68. [CrossRef]

96. Frechon, D.; Exbrayat, P.; Helias, V.; Hyman, L.J.; Jouan, B.; Llop, P.; Lopez, M.M.; Payet, N.; Perombelon, M.C.M.; Toth, I.K.; et al. Evaluation of a PCR kit for the detection of Erwinia carotovora subsp. atroseptica on potato tubers. Potato Res. 1998, 41, 163-173. [CrossRef]

97. Hélias, V.; Hamon, P.; Huchet, E.; Wolf, J.V.D.; Andrivon, D. Two new effective semiselective crystal violet pectate media for isolation of Pectobacterium and Dickeya. Plant Pathol. 2012, 61, 339-345. [CrossRef]

98. Bradford, M.M. A rapid and sensitive method for the quantitation of microgram quantities of protein utilizing the principle of protein-dye binding. Anal. Biochem. 1976, 72, 248-254. [CrossRef]

99. Sambrook, J.; Fritsch, E.F.; Maniatis, T. Molecular Cloning: A Laboratory Manual; Cold Spring Harbor Laboratory Press: Cold Spring Harbor, NY, USA, 1989.

100. Bittinger, M.A.; Handelsman, J. Identification of genes in the rosR regulon of Rhizobium etli. J. Bacteriol. 2000, 182, 1706-1713. [CrossRef] [PubMed]

101. Yap, M.-N.; Yang, C.-H.; Charkowski, A.O. The response regulator HrpY of Dickeya dadantii 3937 regulates virulence genes not linked to the hrp cluster. Mol. Plant. Microbe. Interact. 2008, 21, 304-314. [CrossRef]

102. Jahn, C.E.; Willis, D.K.; Charkowski, A.O. The flagellar sigma factor FliA is required for Dickeya dadantii virulence. MPMI 2008, 21, 1431-1442. [CrossRef] [PubMed]

103. Reverchon, S.; Van Gijsegem, F.; Rouve, M.; Kotoujansky, A.; Robert-Baudouy, J. Organization of a pectate lyase gene family in Erwinia chrysanthemi. Gene 1986, 49, 215-224. [CrossRef]

104. Py, B.; Bortoli-German, I.; Haiech, J.; Chippaux, M.; Barras, F. Cellulase EGZ of Erwinia chrysanthemi: Structural organization and importance of His98 and Glul33 residues for catalysis. Protein Eng. 1991, 4, 325-333. [CrossRef]

105. Wandersman, C.; Andro, T.; Bertheau, Y. Extracellular protease in Erwinia chrysanthemi. J. Gen. Microbiol. 1986, 132, 899-906. [CrossRef]

106. Nykyri, J.; Mattinen, L.; Niemi, O.; Adhikari, S.; Kõiv, V.; Somervuo, P.; Fang, X.; Auvinen, P.; Mäe, A.; Palva, E.T.; et al. Role and regulation of the Flp/Tad pilus in the virulence of Pectobacterium atrosepticum SCRI1043 and Pectobacterium wasabiae SCC3193. PLoS ONE 2013, 8, e73718. [CrossRef]

107. Czajkowski, R.; de Boer, W.J.; Velvis, H.; van der Wolf, J.M. Systemic colonization of potato plants by a soilborne, green fluorescent protein-tagged strain of Dickeya sp. biovar 3. Phytopathology 2010, 100, 134-142. [CrossRef] [PubMed]

108. Sprouffske, K.; Wagner, A. Growthcurver: An R package for obtaining interpretable metrics from microbial growth curves. BMC Bioinform. 2016, 17, 17-20. [CrossRef] [PubMed]

109. Apicella, M.A.; Griffiss, J.M.; Schneider, H. Isolation and characterization of lipopolysaccharides, lipooligosaccharides, and lipid A. Methods Enzymol. 1994, 235, 242-252. [PubMed]

110. Tsai, C.M.; Frasch, C.E. A sensitive silver stain for detecting lipopolysaccharides in polyacrylamide gels. Anal. Biochem. 1982, 119, 115-119. [CrossRef]

111. Czajkowski, R.; van der Wolf, J.M.; Krolicka, A.; Ozymko, Z.; Narajczyk, M.; Kaczynska, N.; Lojkowska, E. Salicylic acid can reduce infection symptoms caused by Dickeya solani in tissue culture grown potato (Solanum tuberosum L.) Plants. Eur. J. Plant Pathol. 2014, 141, 545-558. [CrossRef]

112. R Core Team. R: A Language and Environment for Statistical Computing; R Found. Stat. Comput.: Vienna, Austria, 2016; Available online: http:/ / www.R-project.org/ (accessed on 30 March 2021).

113. Levene, H. Robust tests for equality of variances. Contrib. Probab. Stat. Essays Honor Harold Hotell. 1960, 1, $278-292$. 
114. Shapiro, S.S.; Wilk, M.B. An analysis of variance test for normality (complete samples). Biometrika 1965, 52, 591-611. [CrossRef] 115. Mann, H.B.; Whitney, D.R. On a test of whether one or two random variables is stochastically larger than the other. Ann. Math. Stat. 1947, 18, 50-60. [CrossRef] 